\title{
Detection and Location of Rock Falls Using Seismic and Infrasound Sensors
}

\author{
Valerie L. Zimmer, Department of Geological Sciences, University of Canterbury, \\ Christchurch, New Zealand.
}

Nicholas Sitar, Civil and Environmental Engineering, University of California Berkeley, California, USA.

Corresponding Author: V. L. Zimmer, Department of Geological Sciences, University of Canterbury, Private Bag 4800, Christchurch 8140, New Zealand. (vlzimmer@gmail.com) 
the seismic data in terms of timing, frequency, and P/S/Rayleigh wave phases in order to develop a set of characteristic parameters indicative of rock fall signals. 


\section{Introduction}

Rock falls are the most common type of slope instability in Yosemite Valley, with 40-70 rock falls reported per year (Stock et al., 2013) in an area measuring only $15 \mathrm{~km}^{2}$ and bounded by nearly vertical walls rising $1000 \mathrm{~m}$ above the valley floor. Current rock fall documentation in Yosemite relies solely on people who report observations of rock falls in-progress or the presence of fresh rock fall debris. The reliance on witnesses results in underreporting of observable rock falls and biasing of the data to popular locations. Thus, having a tool capable of passive monitoring of rock falls, such as seismic and acoustic, would significantly augment the existing rock fall documentation and help in identifying patterns of increased (or decreased) rock fall activity. Rock fall patterns are significant because smaller rock falls or loud popping noises occasionally precede larger rock falls in Yosemite Valley for hours or days. Two notable examples of rock falls with precursory activity were the largest historic rock falls at Middle Brother in $1987\left(600,000 \mathrm{~m}^{3}\right)$ and the deadliest rock fall at Yosemite Falls in 1980, killing 3 people and leaving 19 injured (Wieczorek et al., 1995; Stock et al., 2013). Seismic monitoring may also help to assess rock fall dynamics, identify triggering activity, or even rock fall initiation in the case of fracture propagation that causes audible cracking and popping noises (Stock et al., 2012). In order to assess the potential of seismic and acoustic to aid in rock fall monitoring, we installed instrumentation at a historically active cliff in Yosemite Valley over two winter seasons and collected data that helps in assessing the potential for rock fall detection, location, data quality, and interpretation of data in a topographically challenging environment. 
This experiment was not the first attempt to seismically monitor for rock falls in Yosemite Valley. Instruments were installed following the 1996 Happy Isles and the 1999 Glacier Point rock falls, but the results were inconclusive as no notable rock falls occurred during the experiment (Myers et al. 2000). Rock fall events are occasionally large and energetic enough to be detected by nearby strong motion seismic networks. Two notable examples are the two 1996 Happy Isles rock falls (Wieczorek et al., 2000; Uhrhammer, 1996; Morrissey et al., 1999) and the 2009 Ahwiyah Point rock fall (Zimmer et al., 2012), registering as earthquake magnitude-equivalent (Mw) 1.5, 2.1, and 2.4 , respectively. However, these three events were all unusually large $\left(6650 \mathrm{~m}^{3}, 31350\right.$ $\mathrm{m}^{3}$, and, $46700 \mathrm{~m}^{3}$ respectively). Most damaging rock falls in Yosemite are $2-2000 \mathrm{~m}^{3}$ in volume, too small to be detected by existing strong motion seismic networks.

There are numerous scientific studies of Yosemite Valley rock falls aimed at documenting the mechanisms of failure when possible and at identification of rock fall hazard and risk (Guzzetti et al., 2003; Stock and Uhrhammer, 2010; Stock et al. 2011, 2012, 2013, 2014; Wieczorek and Jäger, 1996; Wieczorek and Snyder, 1999; Wieczorek et al. 1995, 1998, 1999, 2000, 2008; Zimmer et al. 2012). The reported number of rock falls has increased from an average rate of 5 per year from 1950-2000 to 41 per year from 2000-2011, as a result of better reporting and documentation (Stock et al., 2013). Thus, understanding the true rate and nature of rock falls in Yosemite is still a subject of research; for many rock falls, there is no known associated trigger, and the mechanics by which the rock fall was initiated is unknown. 
The seismic signature of a rock fall is related to the initial mechanics, dynamics, and physical parameters of a rock fall. The initiation of a rock fall can occur in several ways: the rock can fail in a stress-induced burst, it can slide off a ledge where it has been metastable for years, and it can topple over. Often, a rock fall is not one instantaneous event, but rather a series of events that comprise the initial failure of the cliff, the breakup of the falling rock as it strikes and bounces down the cliff face, multiple large impacts on the ground surface, and the deceleration of rocks as they roll and slide to a stop at the bottom of the talus slope. All of these events are recorded as parts of a single rock fall signal, and individual impacts may or may not be distinguishable.

Most previous studies of the seismic signatures of rock falls and associated physical parameters fall into two broad groups: those detecting large events, often rockslides, at distances $>5 \mathrm{~km}$ and those studying microseismic phenomena associated with cracking at very close range $(<50 \mathrm{~m})$. In the French Alps, studies have linked the seismic characteristics with the physical parameters of rockslides using existing strong motion seismic networks (Dammeier et al., 2011; Deparis et al., 2008). Special monitoring networks have been installed at sites in order to monitor the slide behavior and to attempt the prediction of a potentially catastrophic failure at the Åknes rockslide in Norway (Roth and Blikra, 2004), the Randa rockslide in Switzerland (Burjánek et al., 2010, 2012; Moore et al., 2011; Spillman et al., 2007), the Séchilienne rockslide in the French Alps (Helmstetter and Garambois, 2010; Lacroix and Helmstetter, 2011), and the La Clapière rockslide in the French Alps (Gaffet et al., 2010) 
Microseismic monitoring of rock slopes (mined and natural) is a technique that has existed since the early 1990s (Hardy and Kimble, 1991) and shows potential to detect precursory activity, such as cracking or small rock falls. Rock slope microseismic monitoring is an extension of the techniques developed for underground mining: in one study, shallow underground roof failures were predicted $\sim 75 \%$ of the time (Iannacchione et al., 2005). Microseismic sensors installed in a chalk cliff in France detected cracking two hours before the cliff failed a few meters away (Amitrano et al., 2005). Analysis of microseismic events has provided insight into rock bridge failures leading to rock falls on the Vercors Massif in France (Lévy et al., 2010, 2011). Monitoring of a limestone cliff in southeast France has detected increases in high frequency seismic noise and changes in spectral modes associated with fracture growth and increasing instability prior to failure (Got et al., 2010). A microseismic monitoring system has been installed at the Matterhorn to investigate the link between thermal changes associated with permafrost degradation and rock mass response (Amitrano et al., 2010; Occhiena et al. 2012).

While these previous studies contain important lessons for interpreting seismic data and phenomena associated with rock failures, the steep cliffs and narrow valley dictate that the most common type of hazard are rock falls (not rockslides) of a relatively small volume $\left(<2000 \mathrm{~m}^{3}\right)$ and high free-fall distance $(>100 \mathrm{~m})$ and that instrumentation must be located close enough to detect events $(<1000 \mathrm{~m})$, but cannot be located too closely due to the difficulty of access and the unpredictability of release zone locations (>100 m). In terms of these criteria, volcano-monitoring studies are some of the most similar in 
terms of event volumes and distance between seismic stations and rock fall impacts. Seismic signatures associated with rock falls at volcanoes have been noted since, at least, the early 1970s (Tilling, 1975; Norris, 1994). Hibert et al. (2011) were able to record > 1700 individual rock falls at Dolomieu crater on Réunion Island at distances ranging from $50 \mathrm{~m}$ to $2 \mathrm{~km}$ to the crater rim. Rock falls were distinguished by their impulsive onset and short duration, but the frequency content was heavily dependent on distance to the event with an average of $7 \mathrm{~Hz}$ but impulses up to $40 \mathrm{~Hz}$ at the closest stations. Vilajosana et al. (2008) demonstrated that individual rock fall impacts at recording distances under $200 \mathrm{~m}$ can be distinguished and located with polarization analysis of seismic data. At the "Rappenlochschucht" in the Vorarlberg Alps, Austria, Walter et al. (2012) recorded a large $\left(15,000 \mathrm{~m}^{3}\right)$ rock fall at a distance of $5 \mathrm{~km}$, consisting of several individual impacts and rock fall runout over 20 seconds and preceded by two smaller events described as being similar to avalanche signals lasting 5-7 minutes. Most of the seismic energy was in frequencies less than $20 \mathrm{~Hz}$, and no seismic phases were identifiable from the rock fall or precursory avalanches.

\section{Field Data Collection}

The initial objective of this experiment was to test the feasibility and limitations of a passive seismic monitoring system installed within $1 \mathrm{~km}$ of a potentially active rock fall zone in Yosemite Valley. We initially were permitted to install instruments at one location at one cliff, and the following year permitted to install instruments at 3 locations at one cliff and one location in Yosemite Village. Due to regulations on infrastructure in 
wilderness areas and a requirement to keep installations small and invisible to visitors, we were not permitted to instrument the entire valley, locate instruments on the rim, or have visible large solar panels or antenna. Thus, part of the experiment design was to select an appropriate site for monitoring using a minimum amount of equipment in an inconspicuous location. We targeted the Middle Brother cliff formation due to its history of winter rock falls, access to the cliff face via a ledge system called "Michael's Ledge", relatively inconspicuous (away from hiking trails) location where hikers would be unlikely to see instrumentation, and southeast-facing aspect. Middle Brother is an $800 \mathrm{~m}$ tall rock formation that juts out on the north side of Yosemite Valley (Figure 1). The rock formation has three major rock fall source areas, identified by prominent talus piles below light-colored, highly fractured fresh rock surfaces that contrast with the darker grey, weathered surrounding cliffs (Figure 2). The largest source area, identified as "MBA" in Figure 2, is more than $300 \mathrm{~m}$ wide and $300 \mathrm{~m}$ tall, and sits perched above a section of Michael's Ledge that is notorious for rock falls among rock climbers, who use the ledge to access climbs. Two additional major source areas, MB-B and MB-C, sit to the east of MB-A. Cliff profiles of the three source areas are shown in Figure 3.

Large rock falls have been reported from Middle Brother dating back to before 1851 , including at least one rock fall-induced airblast in January of 1923 (Wieczorek et al., 1992). The largest rock fall in the historical record of Yosemite, on 10 March 1987, occurred at Middle Brother after two days of small rock falls and popping noises. This precursor activity led to the closure of a major road underneath the cliff, only two hours before the rock fall buried it in 4 meters of rock debris totaling $600,000 \mathrm{~m}^{3}$ (Wieczorek 
and Snyder, 2004; Wieczorek et al., 1992, 1995; Yosemite Association, 1987). Rock falls at the Three Brothers, of which Middle Brother is the predominantly active cliff, have been reported, on average, every ten years between 1873 and 1999 and twice a year from 2000 to 2011, due to increased diligence of rock fall reporting (Stock et al., 2013). More than half of the rock falls in this area have occurred during the four winter months of December through March, including five that are classified as very large $\left(\geq 5,000 \mathrm{~m}^{3}\right)$. Winter storms bring freezing temperatures and high amounts of precipitation followed by sunny days and melting of snow and ice; this freeze-thaw cycle may explain the propensity of this cliff to experience winter rock falls. Middle Brother accounts for less than $5 \%$ of the 900 rock falls and landslide events that have been documented in Yosemite between 1857 and 2011, but has produced nearly 25\% of the very large events. The disproportionately high percentage of very large events may be due to the size of the unstable rock fall source areas, possibly caused by relatively high fracture density and complexity of geological contacts at Middle Brother (Peck, 2002).

We installed two seismic sensors at a single station (LB01 in Figure 2) located on "Michael's Ledge" during the winter of 2007-08 as an initial feasibility study (Phase 1). Due to the success of the first installation, we returned in the winter of 2008-09 to deploy a network of seismic sensors and infrasound microphones at four locations (Phase 2). The Phase 2 network, (Figure 2), included two stations at the original location (LB03 and LB05), two stations located higher on the ledge and closer to the Middle Brother rock fall source areas (MB04 and MB06), two stations located at the base of Middle Brother between two prominent talus piles (MB02 and MB07), and a station in Yosemite Village 
$2 \mathrm{~km}$ away with a single seismic sensor (GH08, not shown). The three acoustic infrasound microphones, developed by the InfraVolc group for volcano monitoring (Johnson et al., 2004) were deployed first at station MB06 in December 2008 and moved to station GH08 in January 2009 after sustaining damage from very small rock impacts within the first week of installation.

Data were continuously recorded at 500 or 1000 samples per second (sps) using Reftek RT-130 A/B dataloggers. During Phase 1, we installed a RT 131A 02/03 triaxial accelerometer with a +/- 3g full-scale flat response from DC to $500 \mathrm{~Hz}$ and an SM-6 $8 \mathrm{~Hz}$ triaxial geophone with damping that results in a flat response from $8-1000 \mathrm{~Hz}$ and a sensitivity of $28 \mathrm{~V} / \mathrm{m} / \mathrm{s}$. During Phase 2, L-28 triaxial $4.5 \mathrm{~Hz}$ geophones with damping, a flat response above $4.5 \mathrm{~Hz}$, and a sensitivity of $30.4 \mathrm{~V} / \mathrm{m} / \mathrm{s}$ were the default seismic sensors, but we also installed the RT 131A 02/03 accelerometer at station GH08, and a Terratech SSA-320 triaxial accelerometer with a flat response from DC to $50 \mathrm{~Hz}$ at station MB04. As we were not permitted to bury or alter the site in any way, all instruments were placed on the ground or small ledges, usually under sandbags, except for the MB06 accelerometer, affixed to the wall. Details on the instrumentation are listed in Table 1.

\section{Methodology to Identify Rock Falls: Data Processing, Triggering, and Distinguishing Characteristics}


We extracted rock fall events from the seismic record by: a) determining the seismic characteristics and typical frequency content of rock fall events by reviewing known events; b) comparing them to "noise" events attributable to other sources, such as rain or earthquakes; c) filtering the data to eliminate as much noise as possible; d) developing and running a triggering algorithm; e) determining which triggers warranted close review; and f) manually reviewing unfiltered events to make a final determination.

We found, by reviewing rock fall seismic records that were recorded early in the experiment, that strong, short impacts, signal duration lasting tens of seconds, and a strong seismic response from few $\mathrm{Hz}$ to approximately $20 \mathrm{~Hz}$ is typical (Figure 4a, 4b), with a maximum seismic response over $200 \mathrm{~Hz}$ for some rock falls within $0.5 \mathrm{~km}$. The best predictor of maximum upper frequency is distance to the rock fall although rock fall volumes also affect maximum spectral response. Hibert et al. (2011) observed that rock falls generate most of their energy at $7 \mathrm{~Hz}$ with response up to $40 \mathrm{~Hz}$ with stations at 2 $\mathrm{km}$ and Walter et al. (2012) observed a maximum frequency response of $20 \mathrm{~Hz}$ for a large rock fall $\left(15,000 \mathrm{~m}^{3}\right)$ at $5 \mathrm{~km}$.

\footnotetext{
We also note that geophones proved to be much more sensitive to rock falls and responded at lower frequencies than the two accelerometers. In one case, we had a confirmed case of a small local rock fall that the geophones triggered on but the accelerometer did not, although it did respond to the rock fall at 20-150 Hz (not shown). We experimented with triggering on the full waveform, which was too slow, and with deliberately aliasing the data to capture some of the high frequency content and have
} 
larger sample spacing (and thus smaller file size). We found that the rock fall event triggered successfully using the deliberate-alias method, but also that the triggering algorithm was ten times more sensitive to environmental noise, rendering it difficult to use. The deliberate aliasing method was abandoned since all of the geophones had triggered using the normal method and there were no periods when the accelerometer was running with fewer than 2 other geophones (except for during Phase 1, when single sensor triggers were already being considered).

We post-processed the raw data in order to search for additional rock fall events by filtering, normalization of the data, and then running a short-term average (STA) over long-term average (LTA) triggering algorithm. We determined that filtering in the 1-20 $\mathrm{Hz}$ band was adequate to trigger on rock falls while eliminating some of the weatherrelated noise. We then resampled the data at $25 \mathrm{sps}$ in order to reduce file size and speed up processing times. STA/LTA algorithms are sensitive to mean values, require normalization, and tend to not work well in noisy environments. Traditionally, data are normalized by dividing by the maximum value, but we encountered sensitivity problems due to transient spikes from instrumentation issues. Thus, we normalized the data by removing the mean (typically in 1-hour blocks) and taking the absolute value (Equation 1), effectively setting a new mean equal to 0.7 standard deviations $(\sigma)$ of the original data. Using this method, an STA/LTA $<1$ represents signals that are $<0.7 \sigma$ of the original mean, and an STA/LTA $=2$ represents $1.4 \sigma$.

Equation 1. $P(t)$ is the normalized data, $F(t)$ is the original data.

$$
P(t)=|F(t)-\overline{F(t)}|
$$


The STA and LTA window time lengths, designated triggering ratio, and window overlap are chosen based on the characteristics of the signal of interest (Equation 2). The LTA window was set to $100 \mathrm{~s}$ (longer than a typical rock fall) and the STA window to $1 \mathrm{~s}$ (shorter than a typical rock fall, but longer than a raindrop), with an overlap of $0.5 \mathrm{~s}$ (each datum is overlapped by two windows to ensure that short, weaker events are captured). After some trial and error with known rock falls, we determined that a triggering ratio of 3 (approximately $2 \sigma$ above the original mean) was adequate to detect rock falls while remaining relatively insensitive to normal noise levels.

Equation 2. Calculation of an STA/LTA ratio at any given point in time, $t$. The STA window length $=s$ and LTA window length $=1$.

$$
\frac{S T A(t)}{\operatorname{LTA} A(t)}=\frac{\left(\sum_{i=t-s / 2}^{t+s / 2} P(i)\right) / s}{\left(\sum_{i=t-l / 2}^{t+l / 2} P(i)\right) / l}
$$

Given the site conditions (winter storms, exposed locations), distinguishing noise from events-of-interest was a big part of the processing effort. We recorded $~ 486,000$ triggers on at least one component, and $\sim 66,000$ triggers on all three components of a single seismic instrument (henceforth referred to as a "station trigger"). We ignored all triggers that did not occur on all three seismic components as we felt that a rock fall would be highly likely to trigger triaxially due to complex dynamics. Five stations (LB01, LB03, MB02, MB07, and GH08) experienced issues with memory cache transient spikes when recording at $1000 \mathrm{sps}$, and when this was discovered, sampling rates were dropped to 500 sps. Fortunately, the transient-spike triggers occurred approximately 200 seconds apart and in large sets, providing a way to filter out most of them, thus eliminating $\sim 8,000$ 
triggers and reducing the number of station triggers to $\sim 58,000$ (Table 2). Note that this number does not include infrasound microphone (HDF) triggers, as there were frequently only 2 microphones in operation at any given time due to instrument issues.

During Phase 1, only one station (LB01) was in operation, with two sensors on a 6channel datalogger, recording a total of 891 triggers on both sensors, of which $91(\mathrm{x} 2)$ were transient spikes, leaving 709 total triggers. Out of those, 30 triggers were common to both sensors (henceforth referred to as a "network trigger"). We found that one was an earthquake and 29 were tagged for further review. It should be noted that some geophone-only triggers were also reviewed due to the low triggering rate on the accelerometer.

During Phase 2, 5382 triggers were common to more than one station (e.g. "network trigger"). However, 6 out of 7 stations were co-located, thus leaving only 4 unique locations. Only 1362 of the network triggers occurred at more than one location. Comparison of these common triggers with the earthquake catalogue eliminated another 373, leaving 989 Phase 2 triggers, for a total of 1018 triggers, tagged for further review (Table 2).

Further review requires first identifying which of the $\sim 1000$ triggers have the highest likelihood of being rock falls before creating spectrograms and comparing their characteristics to known events. The remaining triggers were prioritized based on the overall number and/or percentage of stations or locations triggering. The percentage is 
important because the number of stations in operation at any one time was variable, and due to the difficulties with accelerometers, we considered it significant when $100 \%$ of the geophones triggered. During Phase 2, there were 57 events triggering at 4+ stations, 229 events triggering at 3 stations (51/229 triggered 100\% of the geophones), and 703 events triggering at 2 stations (183/703 triggered 100\% of the geophones) (Table 2).

We also compared triggering patterns to weather events to help prioritize: for example rainstorms produce a high number of triggers with occasional coincidental triggers; events triggering at 2 stations but clearly not the entire network during rainstorms were usually ignored. During some periods, only one or two stations were operating either by design or due to instrumentation failure, thus we also carefully reviewed some low priority triggers that occurred, particularly during periods of clear weather when it was otherwise seismically quiet. Note also that stations LB03 and LB05 have triggering rates 5-15 times that of other stations operating during approximately the same times. These triggers are disproportionately occurring between $8 \mathrm{am}$ and $3 \mathrm{pm}$ on days following a winter storm. Their location on a sunny ledge that gets impacted by thawing and falling ice and snow is likely responsible for the higher triggering rates.

We determined the likely origin of an unknown seismic trigger by comparing its unfiltered, full-waveform record with those of known events identified by witness reports and physical evidence. We were fortunate in that confirmed rock falls occurred near our first station within a week of initial deployment, allowing us to ascertain that rock falls have strong spectral energy around $8 \mathrm{~Hz}$ and individual strikes generating energy in 
frequencies from $1 \mathrm{~Hz}$ to $>200 \mathrm{~Hz}$, depending on distance. Rock falls typically have multiple strikes lasting 10 to 60 seconds and some rock falls also have a very weak initial seismic response that appears too small to be an impact on the talus at the base of the cliff (Figure 4a, 13-20s). In contrast, anthropogenic noise, such as construction activity, is variable; often it is regularly spaced in time, restricted to a narrow band, and accompanied by steady vibration associated with engines (Figure 5a). Earthquakes excite the lower $(<20 \mathrm{~Hz})$ frequency band, have distinct $\mathrm{P}$ and S-wave arrivals, and do not exhibit the multiple small impact signal that is characteristic of rock falls (Figure 5b). Rain primarily excites frequencies $>100 \mathrm{~Hz}$ and each raindrop has a very short duration (Figure 5c).. Wind resonates in many different frequency bands, mostly $>20 \mathrm{~Hz}$ and has an emergent onset (Figure 5d). Also shown in Figure 5d (arrow) is a very small rock that impacted the ledge while we were present.

We also found 2 other types of seismic events of unconfirmed origin. The first type has a dominant frequency of $40 \mathrm{~Hz}$ instead of the typical $8 \mathrm{~Hz}$, suggesting both a local origin and a different mechanism causing the radiation of seismic energy. The duration is also much shorter than a typical rock fall (Figure 5e). These events were detected by a single geophone at LB01 during Phase 1 over a 2-day period in March 2008 and a 7-day period in April 2008. Given that they all occurred in the afternoon during periods of clear weather, and that there may have been construction in the vicinity of the cliff, we do not believe that they are attributable to rock falls; we suspect they may be related to human activities or wind and tree movements. 
The second type of unconfirmed seismic event consists of long duration (> $50 \mathrm{~s}$ ), low frequency $(<20 \mathrm{~Hz})$ signals all occurring during or just after snowstorms (Figure 5f). Although these events strongly resemble distant, large rock falls, the observed seismic attenuation between different locations suggests that they are not detectable beyond the immediate vicinity $(\sim 1 \mathrm{~km})$. Thus, we conclude that these long-duration, low-frequency events were most likely snow avalanches, common in Yosemite Valley after snowstorms.

In addition, we observed a diurnal low frequency drift response of our geophones that is correlated with the onset of solar radiation on the sensors, a number of transient spikes that are associated with datalogger memory cache problems, and power outages from multiple days of snow-covered solar panels.

Noise during winter storms is unavoidable, but may be minimized by placing instruments in shady locations and under overhangs to minimize direct rainfall, icefall and geophone drift associated with sun. Locating stations just a few meters apart was useful in order to confirm real, local events. Having stations at multiple locations was critical in identifying significant events and was the most useful tool in locating rock falls. Future seismic networks should continue to co-locate stations for redundancy but also expand the number of locations (if permitted) within a small footprint to aid in detecting and locating local rock falls.

\section{Results}


We detected 12 rock falls over the course of the two winters using the seismic monitoring techniques described herein (Table 3). Eight of the twelve rock falls were observed by witnesses: in some cases the rock fall was seen with the exact time and location noted; in other cases, only an approximate time or location was reported or the rock fall was heard but not seen. The detection limit of rock falls, presented in Figure 6, is a function of distance and rock fall size. It should be noted that both variables are estimates. Volumes are sourced from Stock et al. (2013) or by comparing relative seismic response (Table 3). Distances are approximate to the center of the array at Middle Brother or, for very small events only detected at one station, to the location of the triggered station. The volume of a rock fall is an imperfect proxy for energy release, assuming that fall heights (and thus impact velocities) from source or ledge to talus or ledge mostly fall within a narrow but randomly distributed range, and rocks are released from very steep cliffs. Over $70 \%$ of rock falls occurred post-1980 initiated on slopes $>60^{\circ}$ (Stock et al. 2012). Even with these caveats, it is clear that seismic monitoring is not picking up small and mediumsized rock falls at distances $>1 \mathrm{~km}$, but is quite effective at detecting rock falls $<1 \mathrm{~km}$, including otherwise unnoticed events. Only one rock fall was detected at a location more than $800 \mathrm{~m}$ away (Ahwiyah Point, Figure 1). Of the remaining 11 rock falls, 10 appear to have originated from one of the three main source areas on Middle Brother (Figures 2, 3), while the outlier appears to have originated in Eagle Canyon on the west side of Middle Brother (Figure 1). Herein, the rock falls are divided into two categories for the purpose of discussion: those originating from a single source area as part of an ongoing instability, and those that are independent events. 


\subsection{Ongoing Rock Falls from Single Source Area}

A medium sized $\sim 30 \mathrm{~m}^{3}$ rock fall (Table 3, \#1) was observed falling from source area MB-B (Figure 2) on 18 December 2007 at 16:00 Pacific Standard Time (PST). Eyewitnesses report that rocks came from near the top of the source area, ricocheted off a prominent ledge (Figure 3b), rolled down the talus slope, splintered trees, and impacted the road; one boulder came to rest in the middle of the road. Additional rock falls were observed later the same evening but no specific time was noted: the seismic data show small events at 16:20 and 17:42 (Table 3,\#2 and \#3). Two more rock falls were reliably reported from the same source area on 4 January and 8 January 2008 (\#5 and \#6) and matched to seismic events. Finally, we recorded a rock fall on 28 February 2008 (\#7) that was not observed, but based on the similarities in seismic characteristics (Figure 4), likely originated from the same source.

Rock fall \#1 appears to be the largest event in the series based on seismic energy (Figure 4a), and is the only rock fall known to have extended as far as the road. This event lasted approximately 50 seconds with what appear to be seven to ten rock impacts over a 25 second period. The geophone responded strongly from $8 \mathrm{~Hz}$ (the corner frequency of the instrument) to approximately $50 \mathrm{~Hz}$, with some individual impacts generating energy well above $100 \mathrm{~Hz}$. Close examination of the seismic data reveals that there is a signal arriving at least six seconds prior to the first strong impact pulse, referred to as the "preimpact" signal. The term pre-impact is meant to designate the part of the seismic signal arriving before a much more energetic talus or base impact, however, it may be caused by 
rocks sliding, rolling, and bumping (technically impacting) the cliff face. The spectral energy and duration characteristics of \#5 most closely resembles \#1 (Figure 4b), with 7 to 10 distinct impacts over a 40 s total duration. Rock fall \#7 (Figure 4c) and \#2 (Figure 4d) are the next most similar events in terms of impact strength and duration; neither rock fall was definitively reported or witnessed. Rock falls \#6 (Figure 4e) and \#3 (Figure 4f) show the least amount of correlation with earlier events, with only 3-4 impacts over a 20 second period. These two weakest events are grouped as part of this series due to being very reliably reported (\#6) and occurring during a period just following the first event when additional rock falls are known to have occurred (\#3) In fact, rock fall \#6 might not have been considered definitively a rock fall if it had not been witnessed. Thus, this rock fall places an important bound on the range of seismic character of rock falls originating from a single source area.

\subsection{Rock Falls Observed from Multiple Locations}

There were six rock falls that we consider to be independent of any other rock fall events. We present the records and our analysis of these rock falls in this section. The only recorded rock fall farther than $1 \mathrm{~km}$ was rock fall $\# 12$, the unusually large $\left(46,000 \mathrm{~m}^{3}\right)$ Ahwiyah Point rock fall (Zimmer et al. 2012). This rock fall occurred at a distance of 6.5 $\mathrm{km}$ from the Middle Brother stations, but was large enough to be detected at a distance of $350 \mathrm{~km}$ on the regional strong motion seismic network. Its volume is at least 1000 times larger than any of other recorded rock falls. Even with the large volume, higher frequencies attenuated rapidly and very little signal was recorded above $20 \mathrm{~Hz}$ (Figure 


\begin{abstract}
7a). It is worth noting that several rock falls are known to have preceded and followed the main rock fall at Ahwiyah Point, but none were detected by our network (Figure 6). While the volume of the other Ahwiyah Point rock falls is difficult to ascertain, at least one is estimated to have been $400 \mathrm{~m}^{3}$ (Stock et al. 2013).
\end{abstract}

Rock fall \#11 was heard loudly and lasted tens of seconds and was tentatively located between Middle Brother and El Capitan to the west (Stock et al., 2013). The seismic record of this event resembles other rock falls in that there are at least 5 individual impacts over a 40s period, including a pre-impact signal (Figure $7 \mathrm{~b}$ ). The spectral energy attenuates rapidly above $40 \mathrm{~Hz}$ leading to the conclusion that this rock fall is local but more distant than rock falls at Middle Brother (e.g. Figure 4). Seismic waves arrived west to east, indicating that origin of this rock fall is to the west. Eagle Canyon, to the west of Middle Brother, is a difficult-to-reach area approximately $0.8-1.2 \mathrm{~km}$ away from the Middle Brother seismic stations and is the likely source for this rock fall. However, subsequent field investigation did not reveal any obvious dust or fresh talus deposits.

Rock fall \#8 (Figure 7c) was detected in three different locations and consists of several large impacts over a 30s period. There is strong spectral response $>200 \mathrm{~Hz}$, indicating close proximity, but no witnesses at 2:28am. The GPS timing malfunctioned at station MB06, making comparisons between that station and the other 2 locations impossible. We can state with certainty that the seismic waves arrive first at stations MB02/07 on the talus and later at stations LB03/05 on Michael's Ledge (Figure 2) and also that they did not arrive on a direct path between locations because the back-calculated apparent 
velocities are too high. Fortunately, MB06 was equipped with a geophone and two infrasound acoustic microphones, recording with precise (but not accurate) timing. Thus, taking advantage of the velocity difference between seismic and acoustic waves, we calculate that the source of the rock fall is $270-320 \mathrm{~m}$ to the east. All of the Middle Brother source areas are east of station MB06, but only the top of the talus pile from MB$\mathrm{A}$ is 300 meters away and sitting between stations MB02/7 and LB03/5 (Figure 2).

Rock fall \#9 also showed strong spectral response $>200 \mathrm{~Hz}$ (Figure 7d), indicating close proximity, but was not witnessed at 9:33pm. The infrasound cable at station MB06, located below source area MB-A, was severed by rock impacts during event \#9, and no triggers were recorded at any other station. Thus, we know rock fall \#9 originates from MB-A (Figure 2, 3a) and is small.

Rock fall \#10 was large enough to be detected at three different locations, with most of its spectral energy below $40 \mathrm{~Hz}$ and two impacts exceeding $120 \mathrm{~Hz}$, likely indicating that this event is closer than Eagle Canyon but farther than MB-A (Figure 2), thus placing it at MB-B or MB-C. There were no witnesses, at 9:21 pm, to this rock fall. There are four individual impacts over a $20 \mathrm{~s}$ period with some seismic activity preceding the first impact by five seconds (Figure 7e). The strongest impulses and earliest arriving waveforms were recorded at the easternmost station near the base of the cliff (MB02), supporting the hypothesis that this rock fall occurred at MB-B or MB-C. The impulse spacing and duration is most similar to rock falls from MB-B during the previous winter 
(Figure 4). The topography makes it difficult to calculate location accurately, however a rough 2-D analysis puts it very near to or east of MB02, e.g. MB-C (Figure 2).

Rock fall \#4 was reported by a reliable witness to have originated at MB-C (Figure 2). However, the coincidental timing of this event with the series of rock falls that occurred at source area MB-B cast doubt on the accuracy of the reported location, and we considered both possibilities. Since rock fall \#4 occurred during Phase 1, there was no possibility of resolving its location using P-wave first arrival times. The rock fall consisted of a single, sharp impact with response over $150 \mathrm{~Hz}$ preceded and followed by low frequency signals (Figure 7f). There is a pre-impact signal that starts $7.4 \mathrm{~s}$ earlier than the impact pulse and appears to last about four seconds (Figure $7 f$ at 20 ). The early pre-impact period and the seismically quiescent four seconds leads to the hypothesis that the pre-impact signal is related to the detachment and that the rock went ballistic prior to a single large impact. The seismic character of this rock fall is very different from the other rock falls originating from MB-B in the following ways: it has an earlier initiation signal (7.4 s vs. $5.7 \mathrm{~s}$ ), a seismic quiescent period, and a single impact, as opposed to the rock breaking into multiple blocks up due to contact with the cliff face as seen on all six of the MB-B rock falls (Figure 4). The cliff below MB-C is steeper than that below MBB, making contact with the wall less likely and a single impact more likely (Figure 3). These differences lend credibility to the idea that this rock fall is not part of the rock fall series from the MB-B source area, despite the coincidental timing. Thus we believe that the eyewitness correctly observed the location at MB-C. 


\subsection{Seismic Characteristics of Rock Falls}

Many types of seismic analyses rely on the identification of the different seismic phases, e.g. P, S, and Rayleigh waves. The proximity of seismic stations to rock falls and complexity of topography between source and receiver complicates this process. We calculated the seismic velocity of the first arrivals when possible and determined that they are consistent with $\mathrm{P}$-waves traveling in granite $(4-5.9 \mathrm{~km} / \mathrm{s})$. The proximity of rock fall impacts to the seismic stations $(<800 \mathrm{~m})$ means that $\mathrm{P}$ and $\mathrm{S}$ waves arrive only $\sim 0.1 \mathrm{~s}$ apart, making $\mathrm{S}$ waves difficult to identify in multiple-impact rock falls. The seismic record of the Ahwiyah Point rock fall (\#12), at a distance to $6.5 \mathrm{~km}$, contained evidence of a Rayleigh wave phase but emergent $\mathrm{S}$-waves were only identified at two broadband stations and no S-waves were resolved at the local network (Zimmer et al., 2012)

We analyzed rock falls \#1 and \#4 for seismic wave phases because of the relatively large size of \#1 and the fact that \#4 consisted only of a single impact. Seismic records of both events contain pre-impact signals that appear to be related to the initiation of the rock fall, but the signals are too weak to clearly identify the orientation of first motion. Figure 8 shows the pre-impact signal for \#1 arriving $5.7 \mathrm{~s}$ before the main impact, but the first motion is discernable only on the geophone, as it is obscured in noise on the accelerometer. No pre-impact $\mathrm{S}$ or Rayleigh wave arrivals are discernable for either event. 
In contrast, the first large impact for rock fall \#1 does have a clear first motion: positive in the up, east, and south directions (Figure 8). The orientation of the first impact for rock fall \#4 is less clear because it is partially obscured in the pre-impact signal (not shown). The first impacts for both events have distinct Rayleigh waves but no S-wave arrivals. We identified Rayleigh waves by rotating the three components to radial and transverse directions, low pass filtering them at $10 \mathrm{~Hz}$, and bracketing them around the expected Rayleigh wave arrival time. The Rayleigh waves are oriented in the radial-transverse direction rather than the radial-z direction, meaning that the waves traveled horizontally along the cliff surface (Figure 9).

The timing delay between the pre-impact and first main impact correlates with the initial sliding of a block off of a ledge, likely trajectory, and known mid-cliff impact locations for the 28 March 2009 Ahwiyah Point rock fall (Zimmer et al., 2012). Rocks from rock fall \#1 were observed falling from the top of the MB-B source area and ricocheting off a ledge approximately $160 \mathrm{~m}$ below. This is the expected distance that a rock would freefall in $5.7 \mathrm{~s}$, the observed timing delay. The free-fall time for rock fall \#4 is $7.4 \mathrm{~s}$, corresponding to a ballistic distance of $270 \mathrm{~m}$, approximately the same distance from the top of the talus slope and the bottom of the MB-C source area. Thus, the pre-impact signal relates to some combination of sliding, rolling, and minor contact with the cliff prior to impacting the talus, or in the case of Ahwiyah Point or rock fall \#1, a prominent ledge mid-cliff (main impact). The timing of the pre-impact signal and main impacts can be used to determine whether or not rocks likely originated from the same release points. 


\section{Discussion and Conclusion}

The majority of this effort consisted of running seismic instrumentation under difficult (and noisy) conditions, and then processing the data to find rock falls. The development of the triggering algorithm was helped by two rock falls occurring near the seismic stations within one week of installation, but noise issues still meant that we recorded a very high number of false triggers. After methodically eliminating triggers and carefully reviewing remaining events, we were able to detect twelve rock falls, all but one within 1 $\mathrm{km}$, over the course of two winters. Witnesses reported only eight of the twelve rock falls; the other four would have gone unnoticed if not for seismic monitoring. Rock fall documentation in Yosemite Valley has increased by an order of magnitude in the last 50 years (Stock et al. 2013) but the results from this project indicate that there may still be a significant number of small $\left(5-50 \mathrm{~m}^{3}\right)$ rock falls that are still missing from the database. The results of this study show that small rock falls are detectable at close range $(<1 \mathrm{~km})$ but that even medium to large events attenuate rapidly and are difficult to detect (Figure 6). Future seismic instrumentation would need to be located near enough $(<1 \mathrm{~km})$ to targeted areas in order to pick up these events.

The rock falls that we detected originated from at least five different source areas including four local to the seismic network. Locations were determined using a combination of seismic characteristics and other evidence to pinpoint a likely source area. In most cases, we were not able to calculate an exact location or distance due to a) lack of $\mathrm{P} / \mathrm{S}$ wave phases, b) only a single station recording 8/12 rock falls, c) complex 
topography (unknown wavepath), especially in the case of \#10 and \#11), d) malfunctioning GPS timing (\#8). However, we were able to eliminate source areas by noting, for example, that seismic waves arrived first at one station and later at another, or that only one location triggered, or calculating distance (but not location) based on Pwave and infrasound arrival times and noting which talus slope was at that distance, or noting the presence or lack of high frequency energy. These seismic clues in combination with the existing witness reports and physical evidence allowed us to pinpoint source locations for all but one rock fall.

At Middle Brother, one source area produced six rock falls recorded in two months. Eight of the eleven (Middle Brother) rock falls occurred during or just after winter storms, including six in December during what might reasonably be considered the first winter storm of the season. The remaining three occurred in January and February when snow and ice still covered parts of the cliff. No Middle Brother rock falls occurred during the months of November, March, April, May, or June, even though seismic instruments were in operation for all or part of those months. This result is consistent with the fact that half of the historically documented rock falls from Middle Brother occurred during the winter (Stock et al., 2013)

The seismic character of a rock fall is dependent on the source location, rock fall size, fall distance, and distance to the instruments. P-waves are the most common source of seismic energy. Rayleigh waves appear to be commonly generated by impact events and are rotated and traveling along the surface of the cliffs. In contrast S-waves are nearly 
non-existent. In the absence of reliable $\mathrm{S}$-wave recordings, infrasound recordings provide invaluable information on the distance from the source when multiple stations do not trigger and also provide a way to differentiate the rock fall signals from other sources of noise.

The analysis of the collected data shows that rock falls tend to have several energetic impacts spread out over a 20 - 40 s period. The large impacts are, in general, the source of the rock fall signal, generating strong seismic waves in a broadband frequency range of which the higher frequencies attenuate rapidly with distance, even for very large rock falls. The attenuation of higher frequencies of any given record is an important clue as to the distance to the rock fall. Observed maximum frequencies are $40 \mathrm{~Hz}$ at $6.5 \mathrm{~km}$ (the very large rock fall \#12), $100 \mathrm{~Hz}$ at $0.8 \mathrm{~km}(\# 11), 150 \mathrm{~Hz}$ at $0.5 \mathrm{~km}(\# 2, \# 3, \# 5, \# 6, \# 7)$ and over $200 \mathrm{~Hz}$ at $0.3 \mathrm{~km}(\# 8, \# 9)$, although there is still variability and relatively larger rock falls also tend to have more frequency content in all bands (e.g. \#1, energy up to 200 $\mathrm{Hz}$ at $0.5 \mathrm{~km}$ ). Rock falls from the same source area have very similar seismic duration and impact timing, attributable to similar trajectories, fall heights, and impact locations on the cliff and talus (Figure 4). Most of the recorded rock falls contain multiple distinct impacts. At least three rock falls had a pre-impact signal arriving up to $10 \mathrm{~s}$ before the main impact corresponding to the ballistic distance traveled by rock fragments between the source and impact area. Many of the rock falls were barely detected, their signals barely discernable from the background noise, so it is unsurprising that only the largest impacts (still relatively small) are detected. For other rock falls, there may not be a strong pre-impact signal if, for example, the rock fall originated as hanging debris dislodged 
during a winter storm event. The pre-impact signal may contain clues as to the detachment and initial failure mechanism, but it is likely that fracturing emits a very weak, high frequency seismic signal that dissipates rapidly. Pre-impact signals could be distinguished for the best recordings, but not the orientation of first arrival. Exploration of the source mechanics related to rock fall detachment and fracturing would require a distributed but very close $(<100 \mathrm{~m})$ network in order to measure the weak signal. More data needs to be collected to better understand the relationship between pre-impact signals and rock fall mechanics and dynamics. Overall, our results show that seismic and infrasound monitoring is effective at detecting rock falls and differentiating them from other seismic signals, as well as identifying points of impacts and likely source locations.

\section{Acknowledgements}

This research was supported by the National Science Foundation (NSF) SGER Grant \# 0840580 to N. Sitar and a grant by the Hitachi Corporation. Seismic instruments were provided by the Defense Threat Reduction Agency (DTRA) and by the PASSCAL Instrument Center at New Mexico Tech, of the Incorporated Research Institutions for Seismology (IRIS). The facilities of the IRIS Consortium are supported by the National Science Foundation under Cooperative Agreement EAR-0552316 and by the Department of Energy National Nuclear Security Administration. Data collected for this project is available at the IRIS Data Management Center under network code X7 for 2007-2009. Acoustic microphones were loaned by the InfraVolc Research Group at New Mexico Tech. Data were processed using the Waveform Suite for MATLAB, developed by Celso 
Reyes (Reyes and West, 2011). The authors are grateful to the Yosemite National Park for allowing the deployment of a scientific experiment, to the numerous fieldwork participants, and to Al Leverette and Bob Reinke at DTRA for the instrumentation support and training. The authors wish to especially thank Greg Stock, park geologist, who offered much insight, helped with field site selection and permitting in Yosemite, and edited the manuscript. 


\section{References}

Amitrano, D., J. Grasso, and G. Senfaute (2005), Seismic Precursory Patterns before a cliff collapse and critical point phenomena, Geophys. Res. Lett., 32, doi:10.1029/2004GL022270.

Amitrano, D., M. Arattano, M. Chiarle, G. Mortara, C. Occhiena, M. Pirulli, and C. Scavia (2010), Microseismic activity analysis for the study of the rupture mechanisms in unstable rock masses, Nat. Hazards Earth Syst. Sci., 10(4), 831-841, doi:10.5194/nhess-10-831-2010.

Burjánek, J., Gassner-Stamm, G., Poggi, V., Moore, J. R., \& Fäh, D. (2010). Ambient vibration analysis of an unstable mountain slope. Geophysical Journal International, 180(2), 820-828. doi:10.1111/j.1365-246X.2009.04451.x

Burjánek, J., Moore, J. R., Yugsi Molina, F. X., \& Fäh, D. (2012). Instrumental evidence of normal mode rock slope vibration. Geophysical Journal International, 188(2), 559-569. doi:10.1111/j.1365-246X.2011.05272.x

Dammeier, F., J. R. Moore, F. Haslinger, and S. Loew (2011), Characterization of alpine rockslides using statistical analysis of seismic signals, J. Geophys. Res., 116(F4), F04024, doi:10.1029/2011JF002037. 
Deparis, J., D. Jongmans, F. Cotton, L. Baillet, F. Thouvenot, and D. Hantz (2008), Analysis of Rock-Fall and Rock-Fall Avalanche Seismograms in the French Alps, Bull. Seismol. Soc. Am., 98(4), 1781-1796, doi:10.1785/0120070082.

Gaffet, S., Y. Guglielmi, F. Cappa, C. Pambrun, T. Monfret, and D. Amitrano (2010), Use of the simultaneous seismic, GPS and meteorological monitoring for the characterization of a large unstable mountain slope in the southern French Alps, Geophys. J. Int., 182(3), 1395-1410, doi:10.1111/j.1365-246X.2010.04683.x.

Got, J.-L., P. Mourot, and J. Grangeon (2010), Pre-failure behaviour of an unstable limestone cliff from displacement and seismic data, Nat. Hazards Earth Syst. Sci., $10,819-829$.

Guzzetti, F., P. Reichenbach, G. F. Wieczorek, and G. Survey (2003), Rockfall hazard and risk assessment in the Yosemite Valley, California, USA, Nat. Hazards Earth Syst. Sci., 491-503, doi:10.5194/nhess-3-491-2003.

Hardy, H. R. J., and E. J. Kimble (1991), Application of high frequency AE/MS techniques to rock slope monitoring, in Proceedings of the 5th Conference on Acoustic Emission/ Microseismic Activity in Geologic Structures and Materials, pp. 457-477, Pennsylvania State University, Trans Tech Publications, Clausthal, Germany. 
Helmstetter, A., and S. Garambois (2010), Seismic monitoring of Séchilienne rockslide (French Alps): Analysis of seismic signals and their correlation with rainfalls, $J$. Geophys. Res., 115(F3), F03016, doi:10.1029/2009JF001532.

Hibert, C., a. Mangeney, G. Grandjean, and N. M. Shapiro (2011), Slope instabilities in Dolomieu crater, Réunion Island: From seismic signals to rockfall characteristics, $J$. Geophys. Res., 116(F4), F04032, doi:10.1029/2011JF002038.

Iannacchione, A. T., G. S. Esterhuizen, T. S. Bajpayee, P. L. Swanson, and M. C. Chapman (2005), Characteristics of Mining-Induced Seismicity Associated with Roof Falls and Roof Caving Events, in Proceedings of the 40th U.S. Symposium on Rock Mechanics June 25-29, American Rock Mechanics Association, Anchorage, AK.

Johnson, J. B. (2004), Volcanic eruptions observed with infrasound, Geophys. Res. Lett., 31(14), L14604, doi:10.1029/2004GL020020.

Lacroix, P., and a. Helmstetter (2011), Location of Seismic Signals Associated with Microearthquakes and Rockfalls on the Sechilienne Landslide, French Alps, Bull. Seismol. Soc. Am., 101(1), 341-353, doi:10.1785/0120100110. 
Lévy, C., Baillet, L., Jongmans, D., Mourot, P., \& Hantz, D. (2010). Dynamic response of the Chamousset rock column (Western Alps, France). Journal of Geophysical Research, 115(F4), F04043. doi:10.1029/2009JF001606

Lévy, C., Jongmans, D., \& Baillet, L. (2011). Analysis of seismic signals recorded on a prone-to-fall rock column (Vercors massif, French Alps). Geophysical Journal International, 186(1), 296-310. doi:10.1111/j.1365-246X.2011.05046.x

Moore, J. R., Gischig, V., Burjanek, J., Loew, S., Fäh, Donat (2011), Site Effects in Unstable Rock Slopes: Dynamic Behavior of the Randa Instability (Switzerland), Bull. Seismol. Soc. Am., 101(6), 3110-3116.

Morrissey, M. M., W. Z. Savage, and G. F. Wieczorek (1999), Air blasts generated by rockfall impacts: Analysis of the 1996 Happy Isles event in Yosemite National Park, J. Geophys. Res., 104(B10), 23189-23198.

Myers, S. C., D. Rock, and K. Mayeda (2000), Feasibility of monitoring rock fall in Yosemite Valley using seismic methods, LLNL Report UCRL-ID-137890.

Norris, R. (1994), Seismicity of rockfalls and avalanches at three Cascade Range volcanoes: Implications for seismic detection of hazardous mass movements, Bull. Seismol. Soc. Am., 84(6), 1925-1939. 
Occhiena, C., V. Coviello, M. Arattano, M. Chiarle, U. Morra di Cella, M. Pirulli, P. Pogliotti, and C. Scavia (2012), Analysis of microseismic signals and temperature recordings for rock slope stability investigations in high mountain areas, Nat. Hazards Earth Syst. Sci., 12(7), 2283-2298, doi:10.5194/nhess-12-2283-2012.

Peck, D. L. (2002) Geologic map of the Yosemite Quadrangle, central Sierra Nevada, California, Geologic Investigations Series - U. S. Geological Survey.

Reyes, C. G., and M. E. West (2011), The Waveform Suite: A Robust Platform for Manipulating Waveforms in MATLAB, Seismol. Res. Lett., 82, 104-110, doi:10.1785/gssrl.82.1.104.

Roth, M., and Blikra, L. H. (2004), Microseismic monitoring of the unstable rock slope at Åkernes, in Ber. Geol. B.-A., 82, ISSN-1017-8880.

Spillmann, T., H. Maurer, A. G. Green, B. Heincke, H. Willenberg, and S. Husen (2007), Microseismic investigation of an unstable mountain slope in the Swiss Alps, $J$. Geophys. Res., 112(B7), B07301, doi:10.1029/2006JB004723.

Stock, G. M., and R. A. Uhrhammer (2010), Catastrophic rock avalanche 3600 years BP from El Capitan, Yosemite Valley, California, Earth Surf. Process. Landforms, 35(8), 941-951, doi:10.1002/esp.1982. 
Stock, G. M., G. W. Bawden, J. K. Green, E. Hanson, G. Downing, B. D. Collins, S. Bond, and M. Leslar (2011), High-resolution three-dimensional imaging and analysis of rock falls in Yosemite Valley, California, Geosphere, 7(2), 573-581, doi:10.1130/GES00617.1.

Stock, G. M., S. J. Martel, B. D. Collins, and E. L. Harp (2012), Progressive failure of sheeted rock slopes: the 2009-2010 Rhombus Wall rock falls in Yosemite Valley, California, USA, Earth Surf. Process. Landforms, 37(5), 546-561, doi:10.1002/esp.3192.

Stock, G. M., B. D. Collins, D. J. Santaniello, V. L. Zimmer, G. F. Wieczorek, and J. B. Snyder (2013), Historical rock falls in Yosemite National Park, California (18572011), 17 p. and data files, http://pubs.usgs.gov/ds/746/.

Stock, G. M., Luco, N., Collins, B.D., Harp, E.L., Reichenbach, P., and Frankel, K. (2014), Quantitative rock-fall hazard and risk assessment for Yosemite Valley, Yosemite National Park, California: U.S. Geological Survey Scientific Investigations Report 2014-5129, 52 p., http://dx.doi.org/10.3133/sir20145129.

Tilling, R. I., R. Y. Koyanagi, and R. T. Holcomb (1975), Rockfall seismicity correlation with field observations, Makaopuhi Crater, Kilauea Volcano, Hawaii, J. Res. U.S. Geol. Surv., 3, 345-361. 
Uhrhammer, R. A. (1996), Yosemite rock fall of July 10, 1996, Seismol. Res. Lett., 67, 47-48.

Vilajosana, I., E. Suriñach, A. Abellán, G. Khazaradze, D. Garcia, J. Llosa, A. Abell, and C. Mart (2008), Rockfall induced seismic signals: case study in Montserrat, Catalonia, Nat. Hazards Earth Syst. Sci., 8(4), 805-812, doi:10.5194/nhess-8-8052008.

Walter, M., Arnhardt, C., \& Joswig, M. (2012). Seismic monitoring of rockfalls, slide quakes, and fissure development at the Super-Sauze mudslide, French Alps. Engineering Geology, 128, 12-22. doi:10.1016/j.enggeo.2011.11.002

Wieczorek, G. F., and S. Jäger (1996), Triggering mechanisms and depositional rates of postglacial slope-movement processes in the Yosemite Valley, California, Geomorphology, 15, 17-31.

Wieczorek, G. F., and J. B. Snyder (1999), Rock falls from Glacier Point above Camp Curry, Yosemite National Park, California, U. S. Geological Survey Open-file Report 99-385.

Wieczorek, G. F., and J. B. Snyder (2004) Historical rock falls in Yosemite National Park, California, Open-File Report - U. S. Geological Survey 03-491: http://pubs.usgs.gov/of/2003/of03-491/of03-491.pdf 
Wieczorek, G. F., J. B. Snyder, C. S. Alger, and K. A. Isaacson (1992), Rock falls in Yosemite Valley, California, U. S. Geological Survey Open-file Report 92-387.

Wieczorek, G. F., S. P. Nishenko, and D. J. Varnes (1995), Analysis of rock falls in the Yosemite Valley, California, in Proceedings of the 35th U.S. Rock Mechanics Symposium, edited by J. J. Daemon and R. A. Schultz, pp. 85-89, Reno, NV.

Wieczorek, G. F., M. M. Morrissey, G. Iovine, and J. W. Godt (1998), Rock-fall hazards in the Yosemite Valley, California, U. S. Geological Survey Open-file Report 98467.

Wieczorek, G. F., M. M. Morrissey, G. Iovine, and J. W. Godt (1999), Rock-fall potential in the Yosemite Valley, California, U. S. Geological Survey Open-file Report 99578.

Wieczorek, G. F., J. B. Snyder, R. B. Waitt, M. M. Morrissey, R. A. Uhrhammer, E. L. Harp, R. D. Norris, M. I. Bursik, and L. G. Finewood (2000), Unusual July 10, 1996, rock fall at Happy Isles, Yosemite National Park, California, Geol. Soc. Am. Bull., 112(1), 75-85, doi:10.1130/0016-7606(2000)112<75:UJRFAH>2.0.CO;2.

Wieczorek, G. F., G. M. Stock, P. Reichenbach, J. B. Snyder, J. W. Borchers, and J. W. Godt (2008), Investigation and hazard assessment of the 2003 and 2007 Staircase 
Falls rock falls, Yosemite National Park, California, USA, Nat. Hazards Earth Syst. Sci., 8(3), 421-432, doi:10.5194/nhess-8-421-2008.

Yosemite (1987), The walls came tumbling down, Yosemite Assoc., 49(2), 5.

Zimmer, V. L., B. D. Collins, G. M. Stock, and N. Sitar (2012), Rock fall dynamics and deposition: an integrated analysis of the 2009 Ahwiyah Point rock fall, Yosemite National Park, USA, Earth Surf. Process. Landforms, 37(6), 680-691, doi:10.1002/esp.3206. 


\begin{tabular}{|c|c|c|c|}
\hline \multicolumn{4}{|c|}{ PHASE 1 = LB01 only. PHASE 2 = all other stations } \\
\hline Station & Location & Sensors & Placement \\
\hline LB01 & $\begin{array}{l}\text { 1- LB mid-cliff, } \\
\text { (1480m) }\end{array}$ & $\begin{array}{l}\text { SM-6 } 8 \mathrm{~Hz} \\
\text { geophone }\end{array}$ & On small ledge \\
\hline LB01 & $\begin{array}{l}\text { 1- LB mid-cliff, } \\
\text { (1480m) }\end{array}$ & $\begin{array}{l}\text { RT131 02/03 } \\
\text { accelerometer } \\
\text { (6-channel) }\end{array}$ & On small ledge \\
\hline LBO3 & $\begin{array}{l}\text { 1- LB mid-cliff, } \\
\text { (1480m) }\end{array}$ & $\begin{array}{l}4.5 \mathrm{~Hz} \mathrm{~L}-28 \\
\text { geophone }\end{array}$ & $\begin{array}{l}\text { In sand under } \\
\text { sandbag }\end{array}$ \\
\hline LB05 & $\begin{array}{l}\text { 1- LB mid-cliff, } \\
\text { (1480m) }\end{array}$ & $\begin{array}{l}4.5 \mathrm{~Hz} \mathrm{~L}-28 \\
\text { geophone }\end{array}$ & $\begin{array}{c}\text { On small ledge } \\
\text { under sandbag (not } \\
\text { level) }\end{array}$ \\
\hline MB04 & $\begin{array}{l}\text { 2- MB mid-cliff } \\
(1630 \mathrm{~m})\end{array}$ & $\begin{array}{l}\text { Terratech SSA- } \\
320 \\
\text { accelerometer }\end{array}$ & $\begin{array}{l}\text { Affixed to cliff wall } \\
\text { vertically }\end{array}$ \\
\hline MB06 & $\begin{array}{l}\text { 2- MB mid-cliff } \\
(1630 \mathrm{~m})\end{array}$ & $\begin{array}{l}\text { 4.5 Hz L-28 } \\
\text { geophone \& } \\
\text { infrasound* }\end{array}$ & $\begin{array}{l}\text { In sand under } \\
\text { sandbag }\end{array}$ \\
\hline MB02 & 3- MB base $(1250 \mathrm{~m})$ & $\begin{array}{l}4.5 \mathrm{~Hz} \mathrm{~L}-28 \\
\text { geophone }\end{array}$ & $\begin{array}{l}\text { In sand under } \\
\text { sandbag }\end{array}$ \\
\hline MB07 & 3- MB base $(1250 \mathrm{~m})$ & $\begin{array}{l}4.5 \mathrm{~Hz} \mathrm{~L}-28 \\
\text { geophone }\end{array}$ & $\begin{array}{l}\text { In sand under } \\
\text { sandbag }\end{array}$ \\
\hline GH08 & $\begin{array}{l}4 \text { - Yosemite Village } \\
(1210 \mathrm{~m})\end{array}$ & $\begin{array}{c}\text { RT131 02/03 } \\
\text { accelerometer \& } \\
\text { infrasound* }\end{array}$ & $\begin{array}{l}\text { Placed on frozen } \\
\text { ground }\end{array}$ \\
\hline \multicolumn{4}{|c|}{ LB = Lower Brother (west), MB = Middle Brother (east) } \\
\hline * infras & $\begin{array}{l}\text { nd and 6-channel data } \\
01 / 09 / 09 \text { due to rock }\end{array}$ & $\begin{array}{l}\text { ger were moved } f \\
\text { impacts on the se }\end{array}$ & $\begin{array}{l}\text { om MBO6 to GH08 on } \\
\text { nsor cables }\end{array}$ \\
\hline
\end{tabular}

Table 1. List of seismic stations, locations, sensors, and associated details. 


\begin{tabular}{|c|c|c|c|c|c|c|c|c|c|c|c|c|}
\hline \multicolumn{13}{|c|}{ Station Triggers (not including $\sim 8000$ instrumentation noise triggers) } \\
\hline Station & \multicolumn{2}{|c|}{ LB01 } & \multirow{2}{*}{$\frac{\text { LB03 }}{\text { geo }}$} & \multirow{2}{*}{$\frac{\text { LB05 }}{\text { geo }}$} & \multirow{2}{*}{$\frac{\text { MB02 }}{\text { geo }}$} & \multirow{2}{*}{$\frac{\text { MB07 }}{\text { geo }}$} & \multicolumn{2}{|c|}{ MB06 } & \multicolumn{3}{|c|}{$\mathrm{GH} 08$} & \multirow{2}{*}{$\begin{array}{l}\text { MB04 } \\
\text { accel }\end{array}$} \\
\hline Sensor & acc & geo & & & & & geo & $\mathrm{HDF}^{*}$ & geo & accel & $\mathrm{HDF}^{*}$ & \\
\hline Days Operating & 130 & 130 & 173 & 134 & 198 & 115 & 71 & 28 & 30 & 57 & 46 & 144 \\
\hline 3-comp Triggers & 87 & 622 & 26861 & 18734 & 7195 & 1108 & 2583 & 3573 & 190 & 142 & 702 & 22 \\
\hline \multicolumn{13}{|c|}{ Network Triggers (not including earthquakes) } \\
\hline \multicolumn{3}{|c|}{ Seismic Sensors Triggering } & \multicolumn{2}{|c|}{ Any } & 4+ & 3 & 2 & \multirow{2}{*}{\multicolumn{5}{|c|}{$\begin{array}{l}{ }^{*} \text { Only } 2 \text { microphones for all or part } \\
\text { of monitoring time, thus this does } \\
\text { not represent the true triggering } \\
\text { value }\end{array}$}} \\
\hline \multicolumn{3}{|l|}{ Phase 1} & \multicolumn{2}{|c|}{889} & - & - & 29 & & & & & \\
\hline \multicolumn{3}{|l|}{ Phase 2 Total } & \multicolumn{2}{|c|}{$>60000$} & 57 & 229 & 703 & & & & & \\
\hline \multicolumn{3}{|c|}{ Phase 2 100\% geophone trig. } & \multicolumn{2}{|c|}{$>60000$} & 57 & 51 & 183 & & & & & \\
\hline
\end{tabular}

Table 2. Station triggers (top) shows the number of triggers recorded by three seismic components and infrasound (HDF), and the total number of days each station was operating. Network triggers (bottom) lists the number of multi-station or multi-sensor triggers (e.g. 4+, 3, or 2 stations). 


\begin{tabular}{|c|c|c|c|c|c|c|c|}
\hline$\#$ & Inferred Location & Date & $\begin{array}{l}\text { Loca } \\
\text { Time }\end{array}$ & $\begin{array}{l}\text { Estimated } \\
\text { Volume }\end{array}$ & $\begin{array}{l}\text { Evidence or } \\
\text { Witnesses }\end{array}$ & Seismic Stations & $\begin{array}{l}\text { Distance from } \\
\text { Seismic to } \\
\text { Talus Impact } \\
\text { (m)*** }\end{array}$ \\
\hline & & Phase 1 & PST & $m^{3}$ & & in operation & \\
\hline 1 & Middle Brother MB-B & $18 / 12 / 07$ & $16: 00$ & $\sim 30^{*}$ & $\begin{array}{l}\text { Seen at } 16: 00 \text { at } M B- \\
B, \text { boulders in road }\end{array}$ & LB01 & 500 \\
\hline 2 & Middle Brother MB-B & $18 / 12 / 07$ & $16: 20$ & $\sim 15^{*}$ & $\begin{array}{l}\text { Seen in PM } \\
\text { (unspecified time) } \\
\text { after event \#1 }\end{array}$ & LB01 & 500 \\
\hline 3 & Middle Brother MB-B & $18 / 12 / 07$ & $17: 42$ & $\sim 10^{*}$ & $\begin{array}{l}\text { Seen in PM } \\
\text { (unspecified time) } \\
\text { after event \#1 }\end{array}$ & LB01 & 500 \\
\hline 4 & Middle Brother MB-C & $19 / 12 / 07$ & $15: 28$ & $8^{* *}$ & $\begin{array}{l}\text { Seen at } 15: 32 \text { at MB-C } \\
\text { (reliable) }\end{array}$ & LB01 & 700 \\
\hline 5 & Middle Brother MB-B & $4 / 01 / 08$ & $18: 33$ & $\sim 20^{*}$ & Seen at $\sim 19: 00$ & LB01 & 500 \\
\hline 6 & Middle Brother MB-B & $8 / 01 / 08$ & $10: 17$ & $10 * *$ & Eyewitness (reliable) & LB01 & 500 \\
\hline \multirow[t]{2}{*}{7} & Middle Brother MB-B & 28/02/08 & 15:55 & $\sim 15^{*}$ & No & LB01 & 500 \\
\hline & & Phase 2 & & & & & \\
\hline 8 & Middle Brother MB-A & $15 / 12 / 08$ & $2: 24$ & $\sim 10^{*}$ & No & $\begin{array}{l}\text { MB02 LB03 LB05 } \\
\text { MB06 MB07 }\end{array}$ & 300 \\
\hline 9 & Middle Brother MB-A & $20 / 12 / 08$ & $21: 33$ & $\sim 5^{*}$ & $\begin{array}{l}\text { No witnesses; } \\
\text { damaged cable }\end{array}$ & $\begin{array}{l}\text { MB06 (no other } \\
\text { stations detected } \\
\text { this event) }\end{array}$ & 300 \\
\hline 10 & $\begin{array}{l}\text { Middle Brother } \\
\text { unknown }\end{array}$ & $14 / 01 / 09$ & $21: 21$ & $\sim 5^{*}$ & No & $\begin{array}{l}\text { MB02 LB03 LB05 } \\
\text { MB06(HDF) } \\
\text { MB07 }\end{array}$ & 300 \\
\hline 11 & Eagle Canyon & $17 / 01 / 09$ & $13: 54$ & $200 * *$ & $\begin{array}{l}\text { Heard west of Middle } \\
\text { Brother }\end{array}$ & $\begin{array}{l}\text { MB02 LB03 LB05 } \\
\text { MB06 GH08(HDF) }\end{array}$ & 800 \\
\hline 12 & Ahwiyah Point & 28/03/09 & $\begin{array}{l}5: 26 \\
\text { (PDT) }\end{array}$ & $46700 * *$ & $\begin{array}{l}\text { Substantial (fresh } \\
\text { talus, visual, audio) }\end{array}$ & $\begin{array}{l}\text { MB02 LB03 LB05 } \\
\text { MB07 MB04 } \\
\text { GH08(HDF) }\end{array}$ & 6500 \\
\hline \multicolumn{8}{|c|}{ * Volumes are determined based on relative seismic response using events \#4 and \#6 as baselines due to highly reliable witnesses. } \\
\hline \multicolumn{8}{|c|}{ ** Estimated volume from Stock et al. (2013) } \\
\hline & stances are approxim & verage & loc & $M$ & her lovelude & $r$ & is \\
\hline
\end{tabular}

Table 3. List of rock falls detected seismically. Column 1 assigns a number used to refer to each rock fall in the text and figures. 


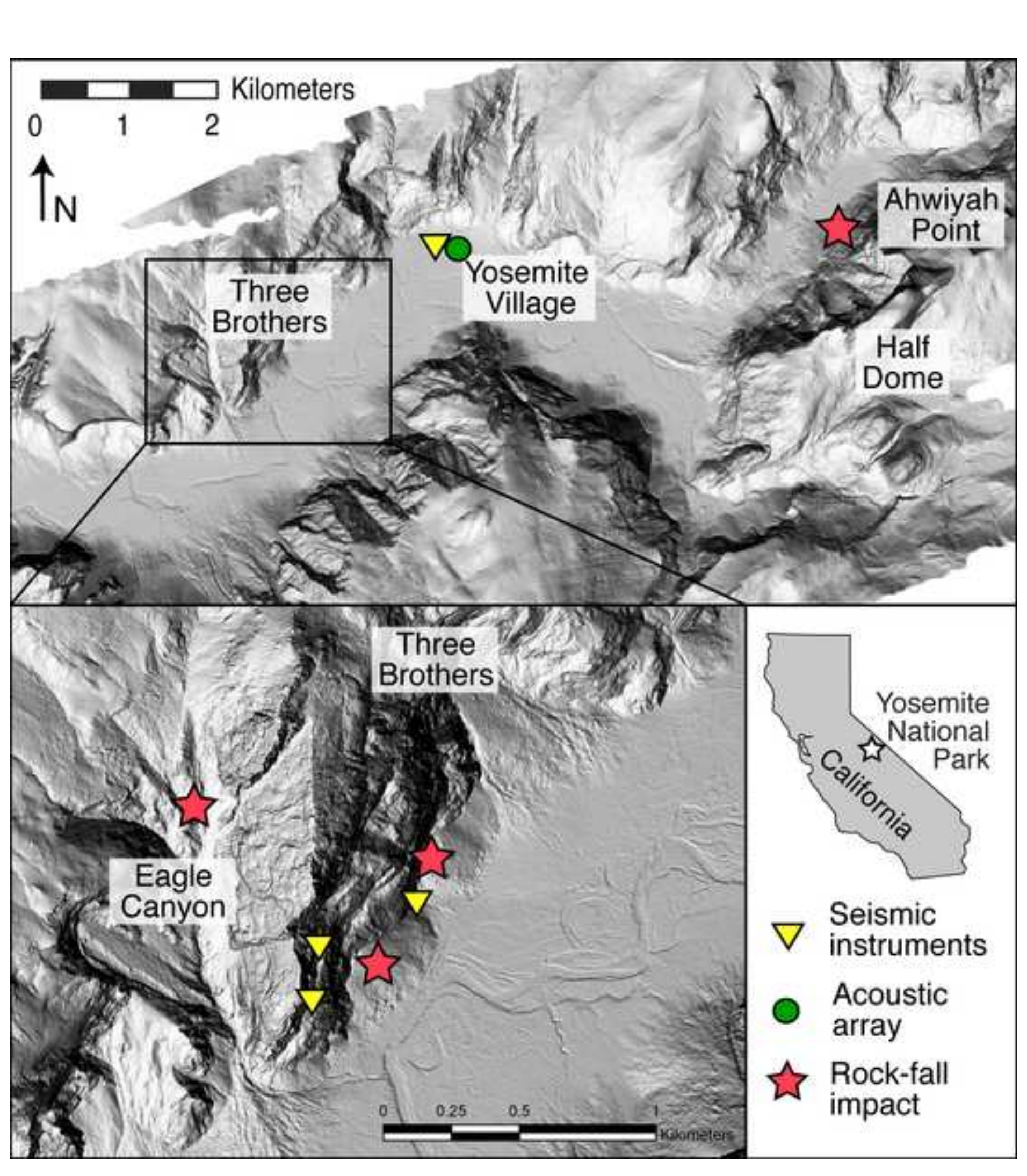




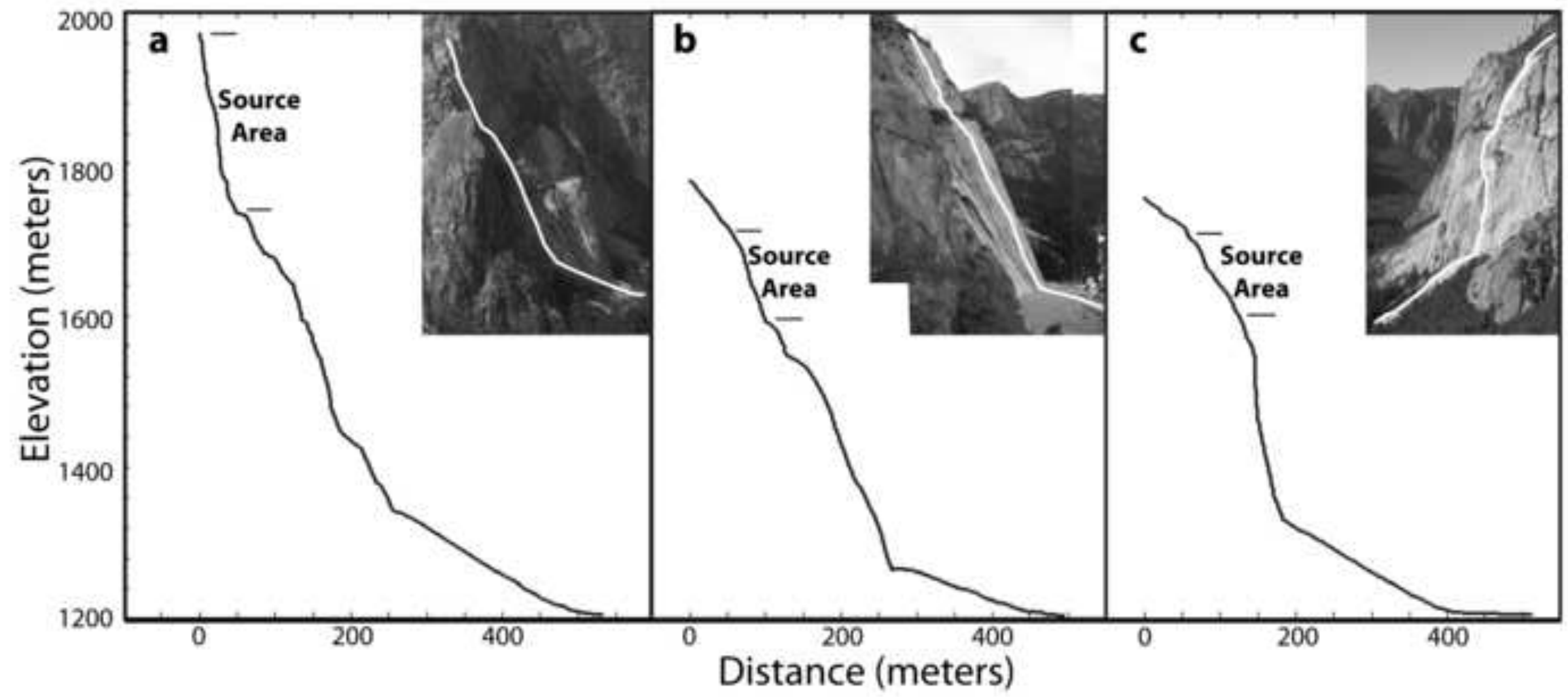




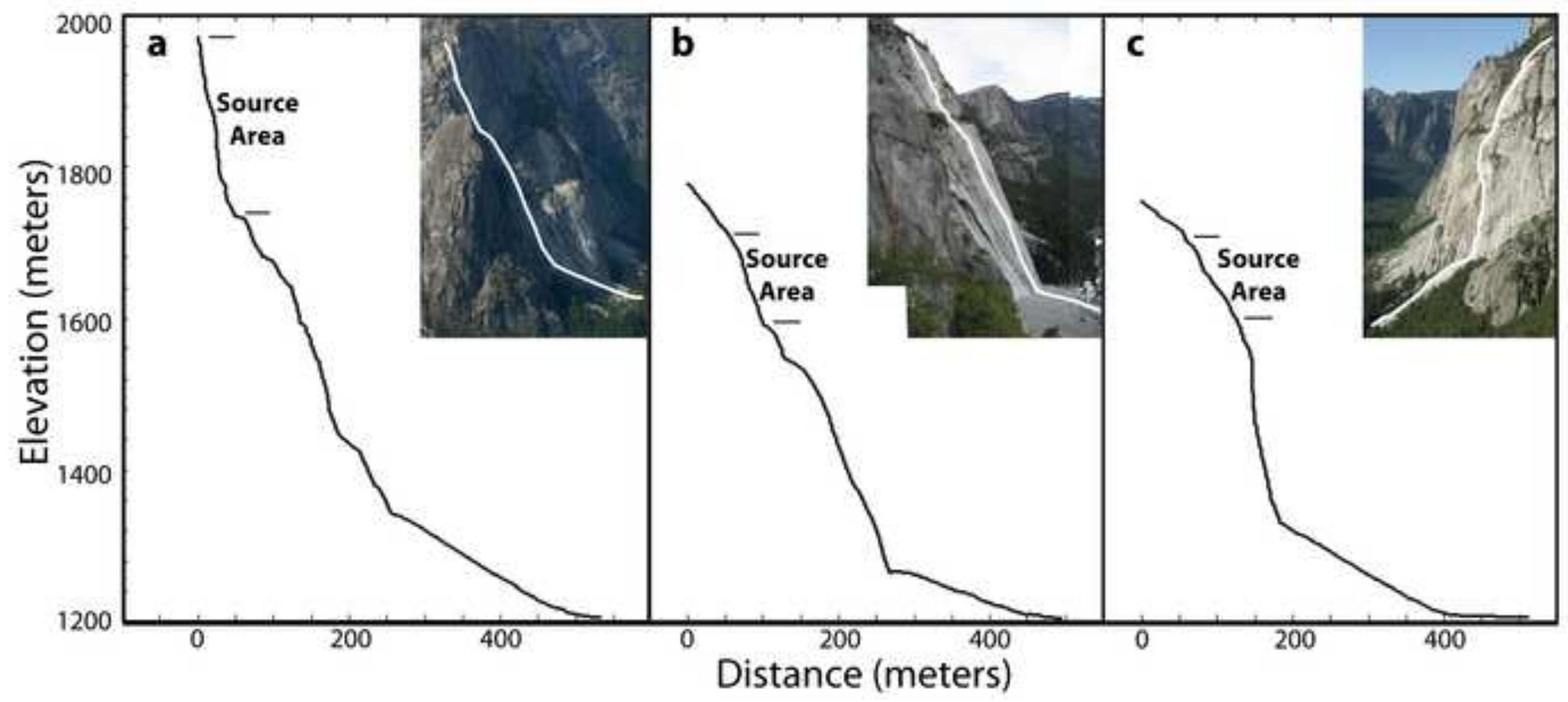



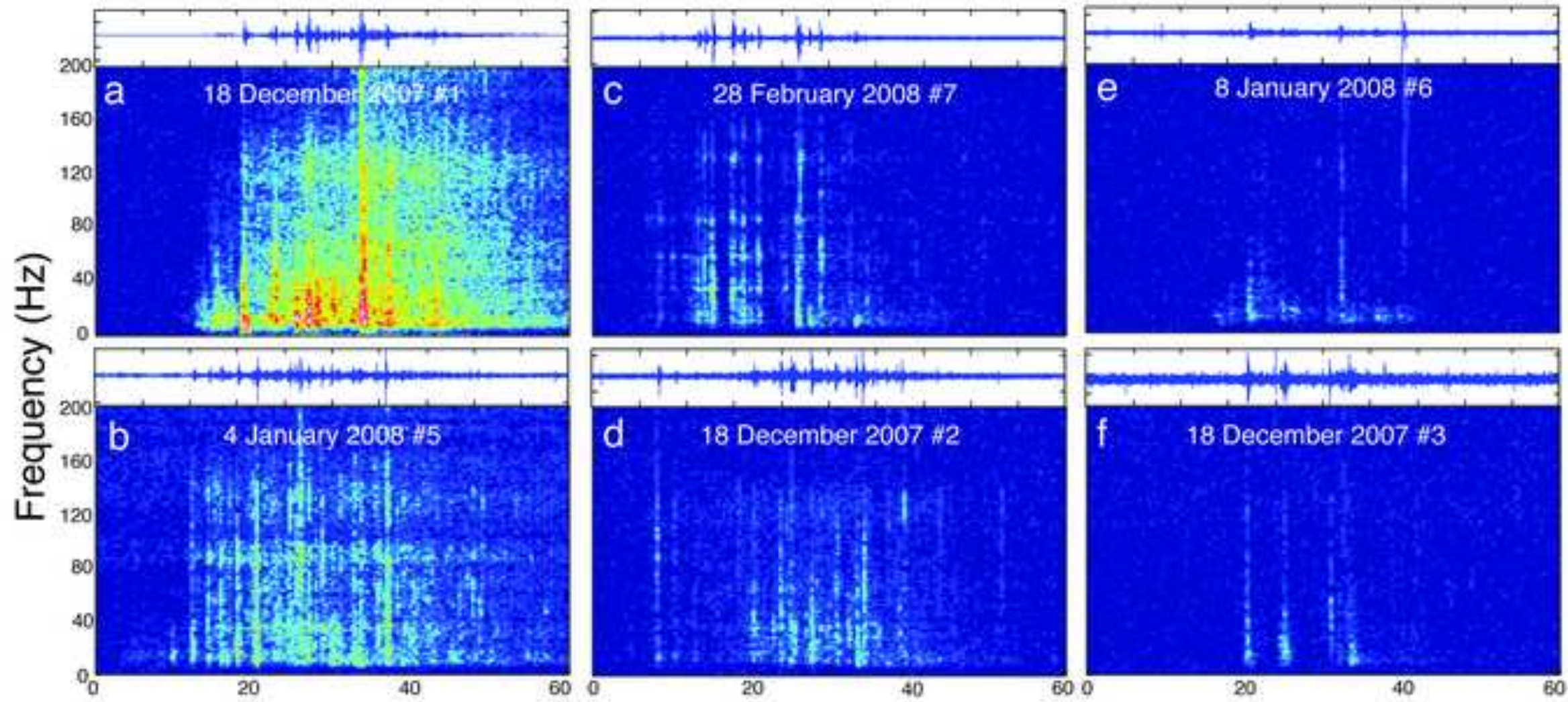

Time (Seconds)

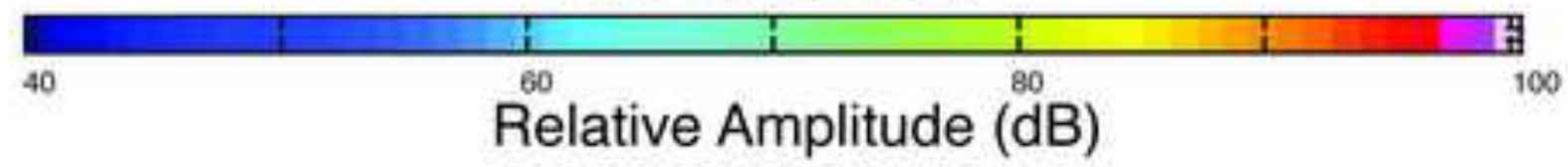



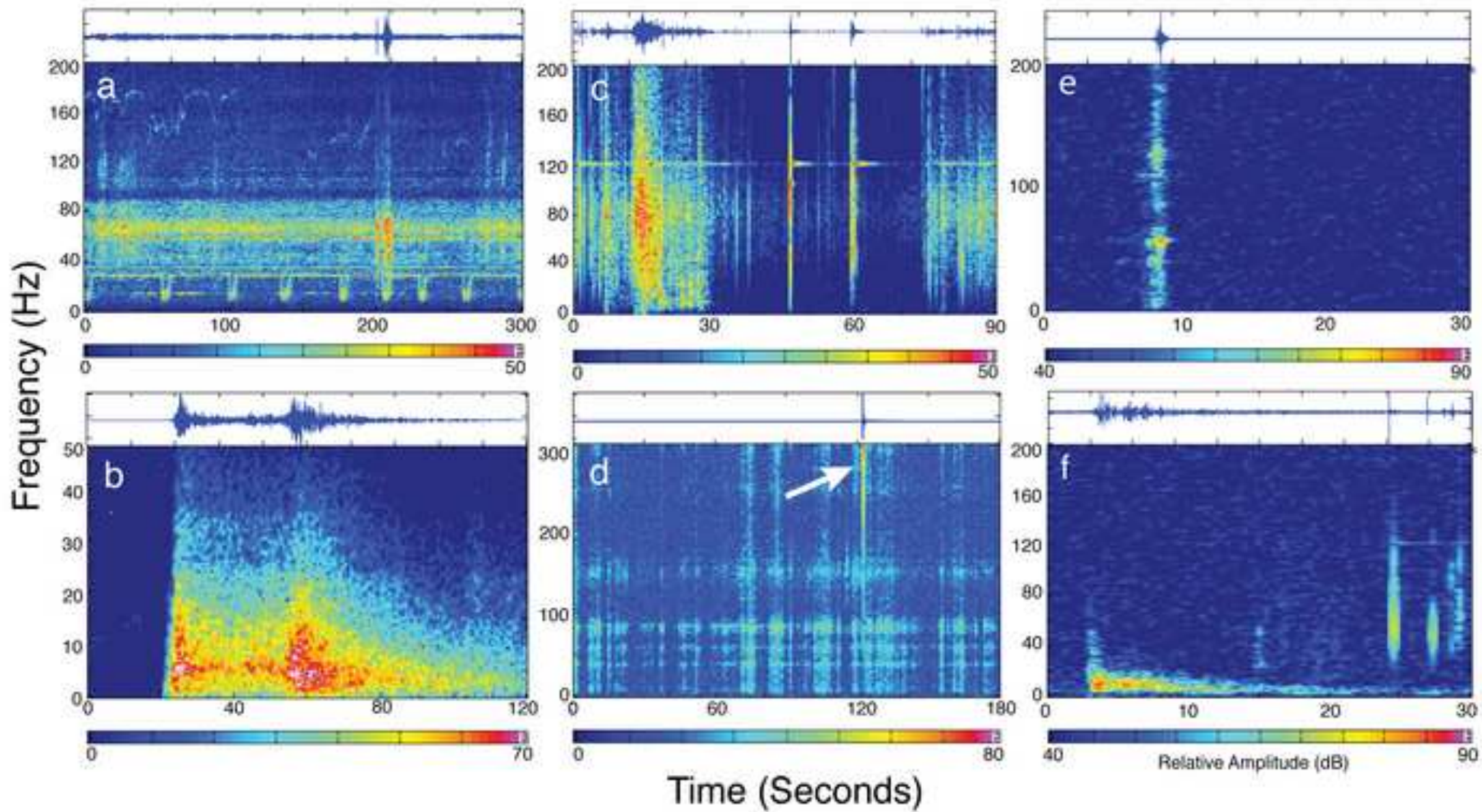

Time (Seconds) 


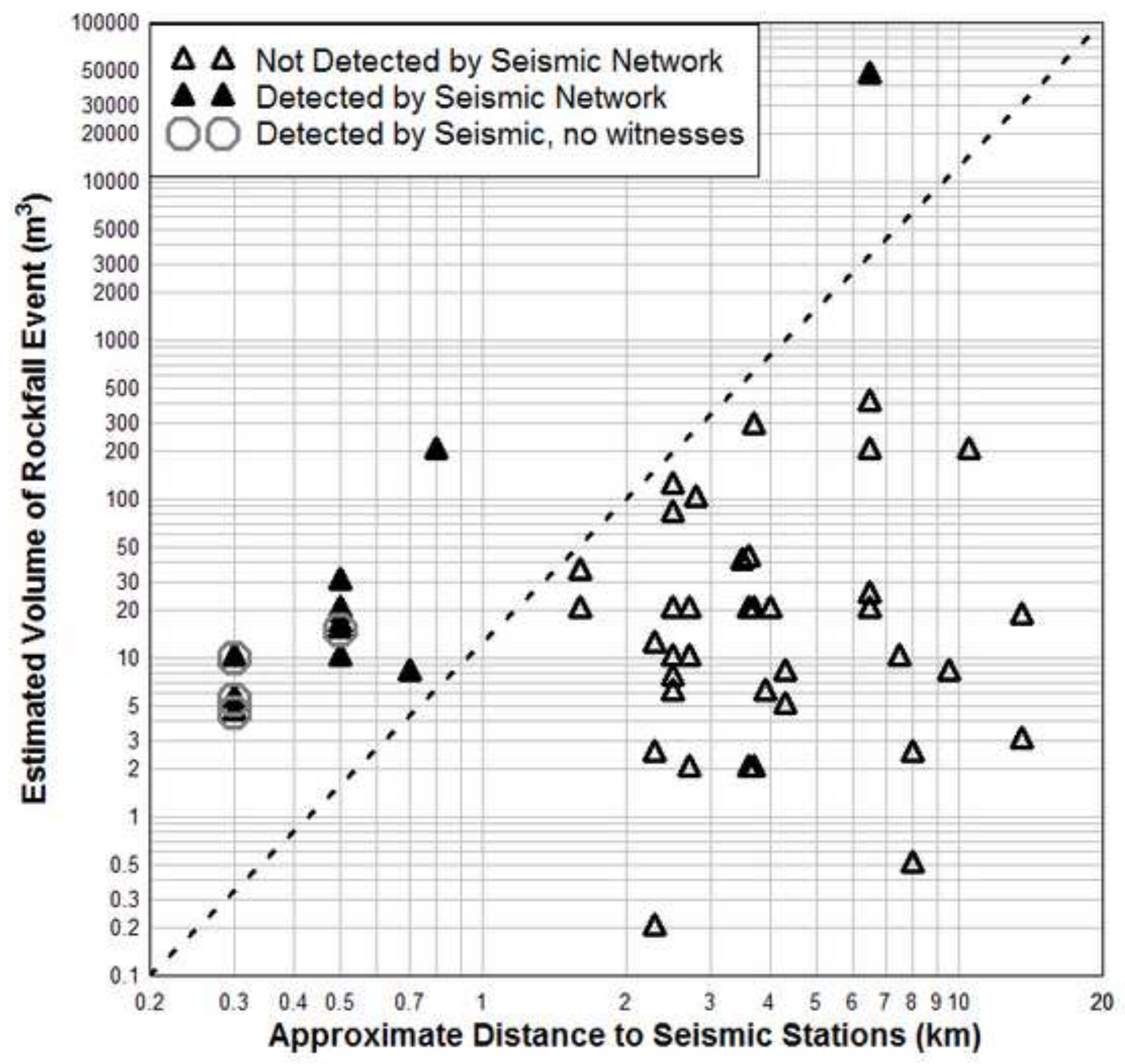



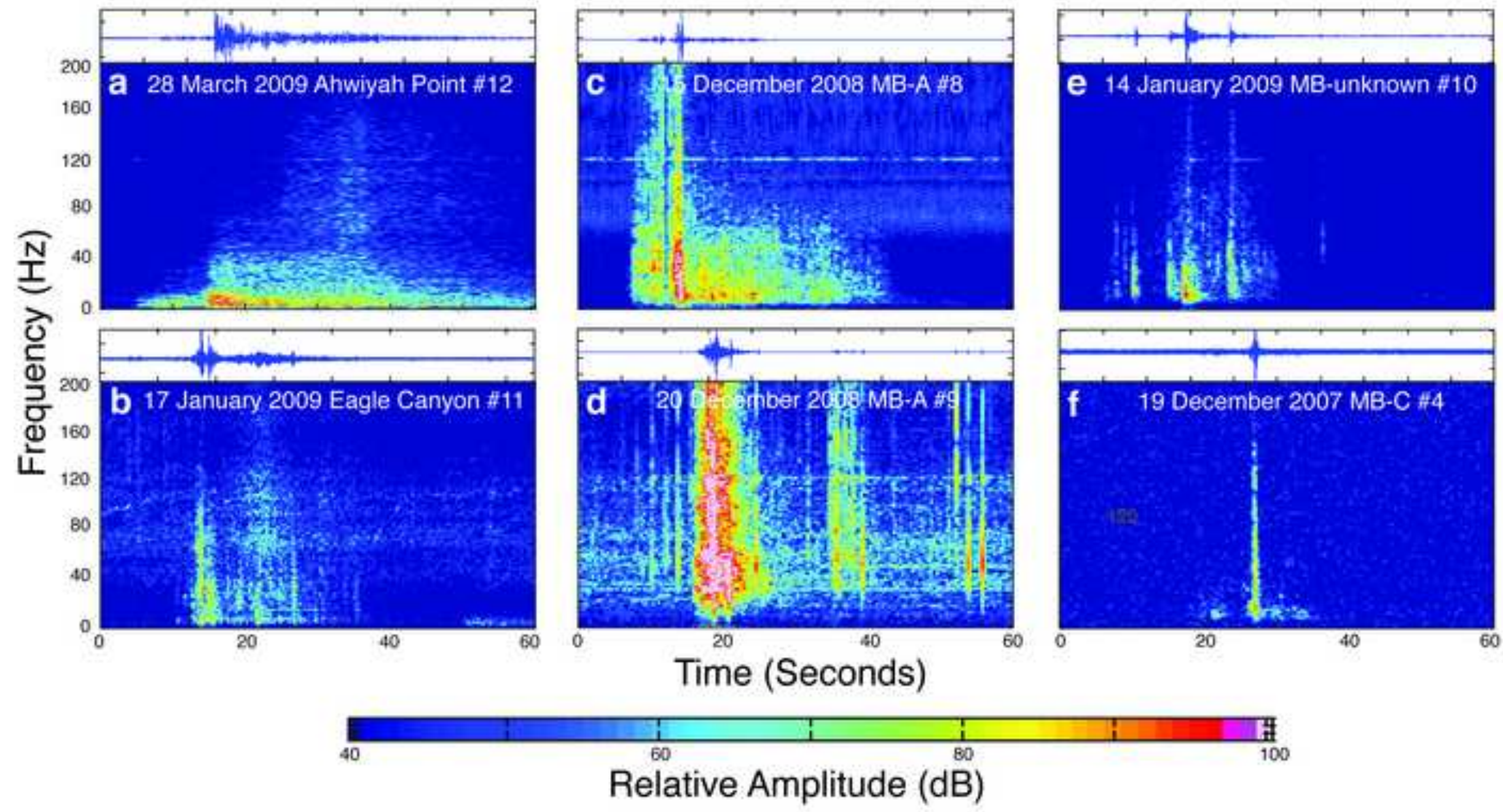
18 December 2007 16:00:22 Filtered 1-20 Hz

First Motion of Signal

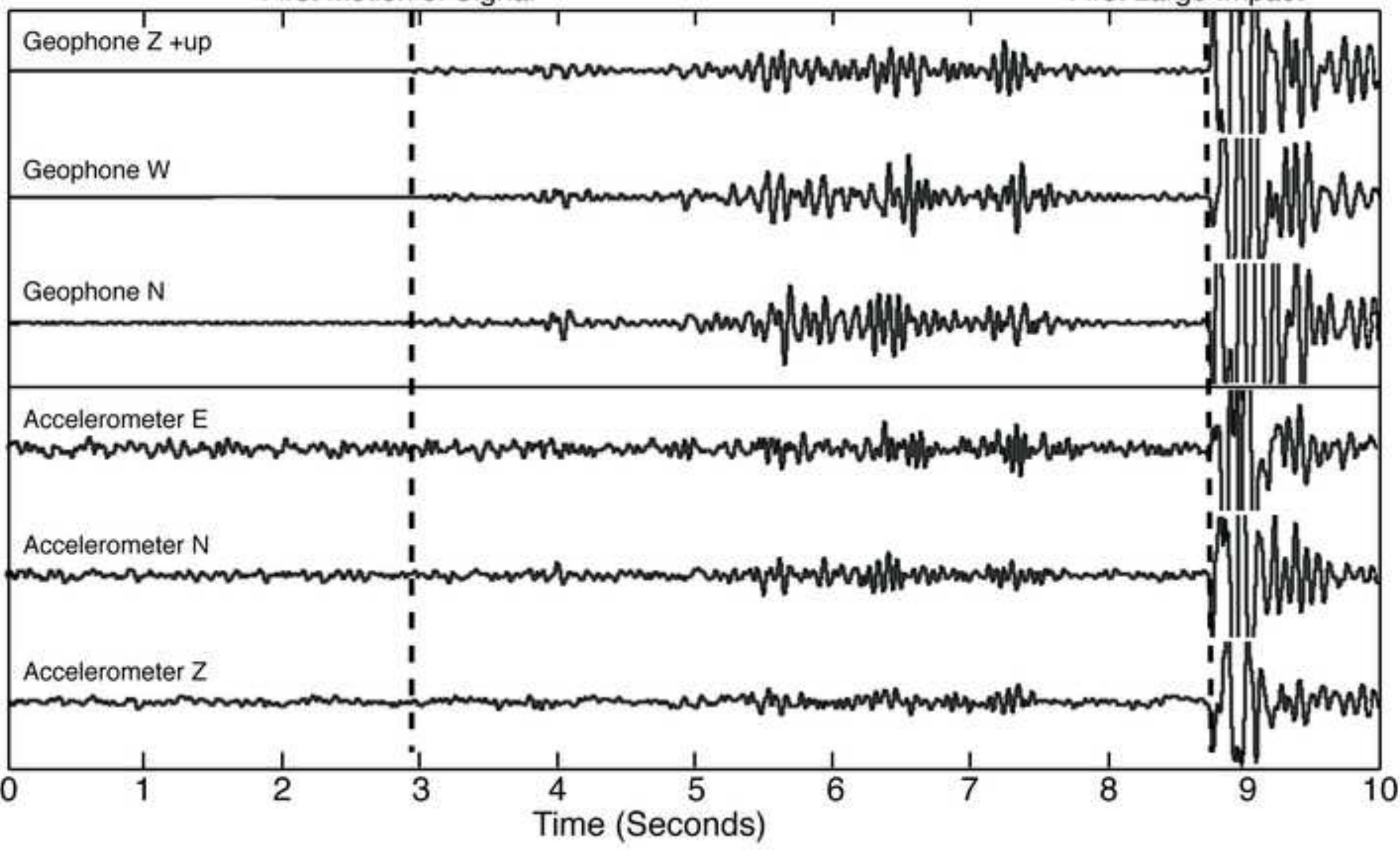




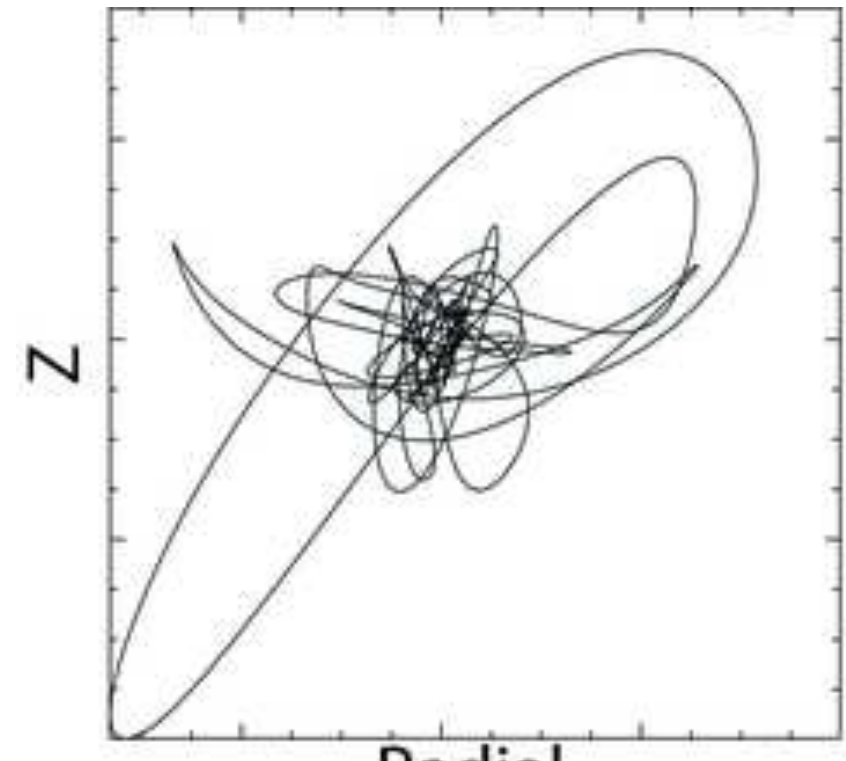

Radial

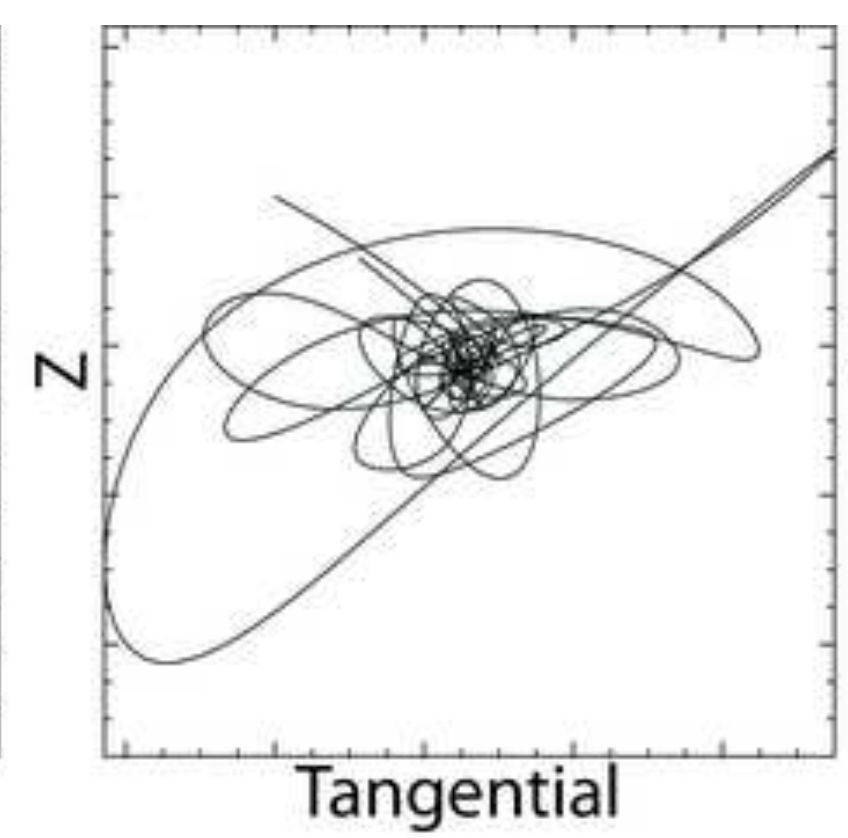

Tangential

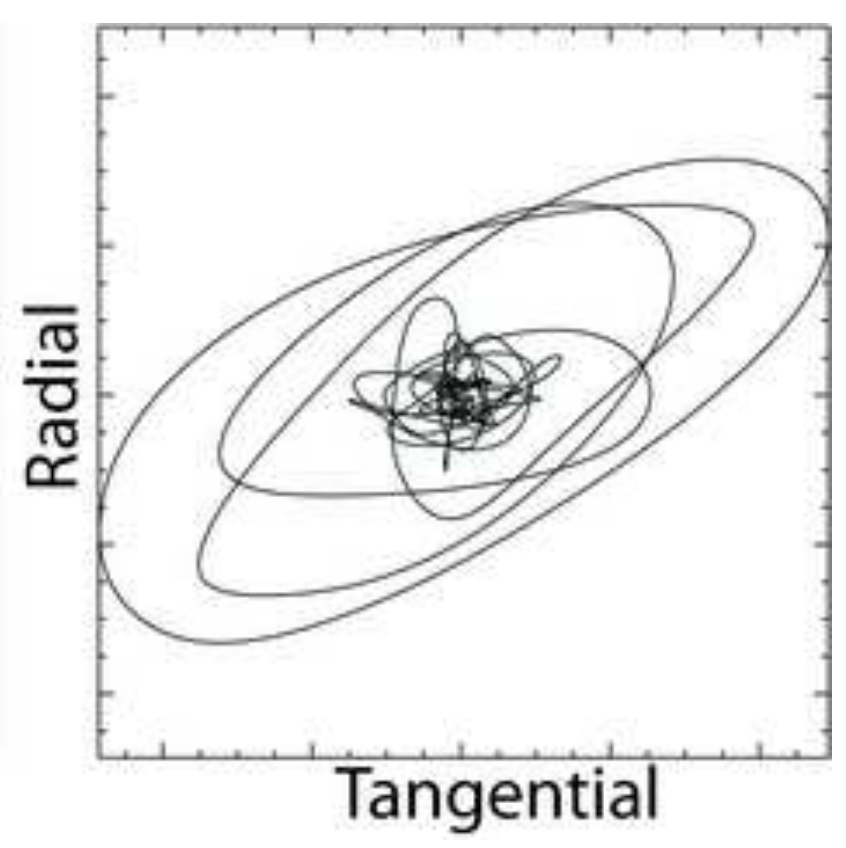


Figure 1. Map showing the location of the seismic instruments at the Three Brothers (including Middle Brother) and in Yosemite Village. Locations of inferred rock fall impacts recorded by the seismic instrumentation are also shown.

Figure 2. Large historical rock fall source areas on Middle Brother (MB-A, MB-B, MBC) and locations of seismic stations (triangles). Station LB01 was operational during Phase 1 while all other stations were operational during Phase 2.

Figure 3. Photos and vertical profiles of the cliffs at a) MB-A b) MB-B and c) MB-C

Figure 4. Spectrogram of rock falls occurring at MB-B from 18 Dec 2007 to 28 Feb 2008 during Phase 1, ordered from largest to smallest. Numbers correspond to reference numbers listed in Table 3 . Time is on the $\mathrm{x}$ axis $(0-60 \mathrm{~s})$ and frequency on the $\mathrm{y}$-axis $(0-$ $200 \mathrm{~Hz}$ ). Brighter colors indicate stronger (and thus larger) seismic response. Three of the rock falls were reported reliably ( $a, b$ and e); two occurred during a period when rock falls were reported with indefinite time ( $\mathrm{d}$ and $\mathrm{f}$ ); and one was only observed seismically and grouped with the others due to similarities in character (c). 
Figure 5. Spectrogram examples of common seismic noise, including: (a) construction activity, (b) earthquakes, (c) heavy rain (d) wind and a micro-rock impact at $120 \mathrm{~s}$, (e) an event of unknown origin occurring during the afternoon in good weather but probably not a rock fall and (f) a snow avalanche 3-20s followed by very local small impacts (25-30 s) which may be ice impacting the slope during a snowstorm. Time is on the $\mathrm{x}$ axis and frequency on the y-axis. Brighter colors indicate stronger (and thus larger) seismic response.

Figure 6. Rock falls detected by the seismic network comparing with known rock falls, which were not detected. Note that both volume and distance is estimated (not exact) from seismic records and/or Stock et al. [2013].

Figure 7. Spectrograms of rock falls occurring at (a) Ahwiyah Point at $6.5 \mathrm{~km}$, (b) Eagle Canyon at $\sim 800 \mathrm{~m}$, which was heard but not seen, and (c, d, e, f) Middle Brother at $<600$ m. Of the Middle Brother rock falls, only (f) was witnessed as the other three occurred at night. Physical evidence for (d) was found in the form of a damaged infrasound cable. Time is on the $\mathrm{x}$ axis (0-60 s) and frequency on the y-axis $(0-200 \mathrm{~Hz})$. Brighter colors indicate stronger (and thus larger) seismic response. Numbers correspond to reference numbers listed in Table 3.

Figure 8. Seismograms of the first motions of the 18 December 2007 16:00 (PST) rock fall at MB-B, filtered 1-20 Hz. The first motion of the "pre-impact" signal, at $3 \mathrm{~s}$, 
is only distinct on the geophone records (top), although later arrivals (starting at 5.3 s) are clear on the accelerometer (bottom) as well. The first main impact, at $8.7 \mathrm{~s}$, is visible on all records.

Figure 9. Rayleigh wave particle motions for the 19 December 2007 rock fall, bracketed around the expected arrival time and low pass filtered at $10 \mathrm{~Hz}$. The Rayleigh waves are recorded in the radial-tangential plane because they are traveling along the surface of a nearly vertical cliff. 